UNITED STATES

DEPARTMENT OF THE INTERIOR GEOLOGICAL SURVEY

\section{OFR: $65-45$}

CARBON BACKS

NM 123, Part 9

SOUTHWESTERN CLOSED BASINS - BY GENE DOTY 
this major drainage area are

Counties and parts of counties included within the area are

- The larger cities and villages in the area are

Description

Geography

Drainage areas

Stream systems river and tributaries

Topography and physiographic provinces

Topographic mapping

Geology

Sedimentary rocks

Igneous rocks

Minerals

Geologic mapping

Soils and vegetation

Soils

Vegetation

Hydrology

General (weather stations, temperature, precipitation)

Surface water

Streamflow measuring network

Water yield, annual runoff 


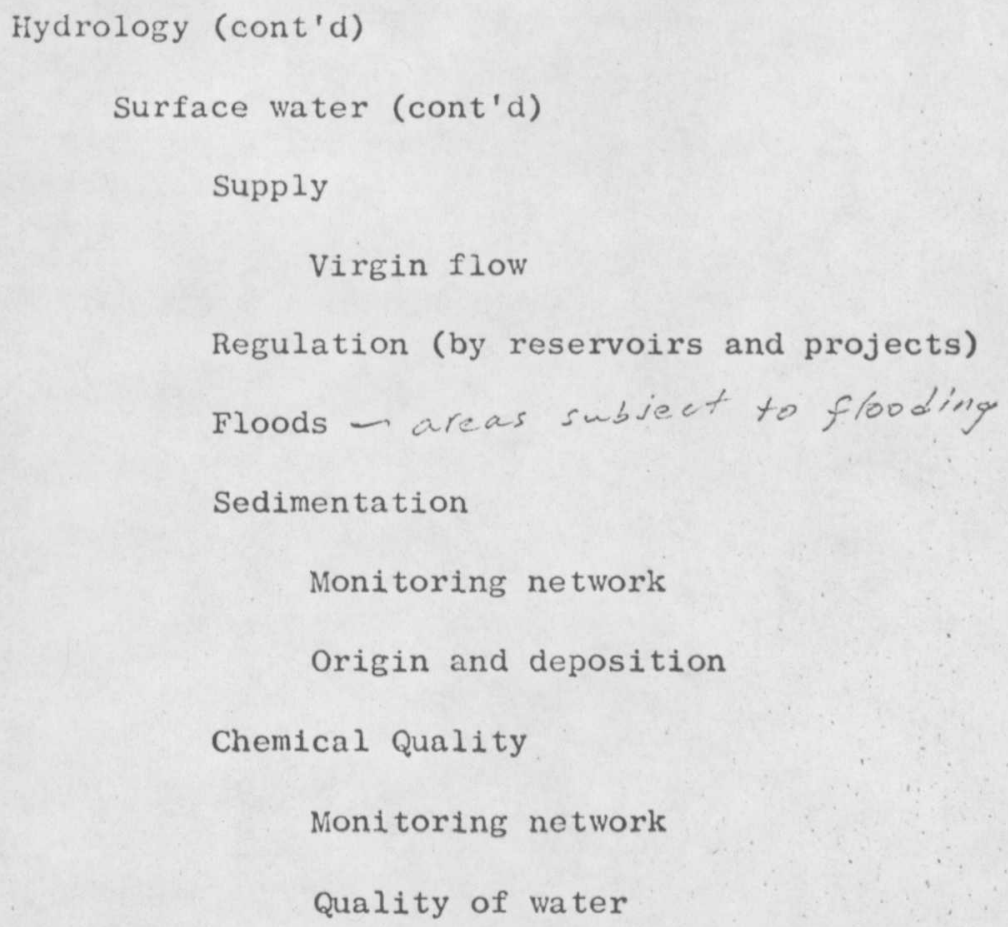



Wiater Development and Use (cont'd)

Beneficial uses (cont'd)

Agriculture

Non-irrigated

(Items as dry-land, rangeland, livestock, land treatment, $\therefore \quad$ erosion control, etc)

Irrigated

(Items as project lands, crops, water requirements, drainage problems, etc.)

Other consumptive uses

Reservoir evaporation

Native vegetation and phreatophytes

Channel losses

Summary Table of water uses Item

Agriculture

Municipal and Industrial

Rural domestic and livestock

Power production

Recreation, Fish \& Wildlife

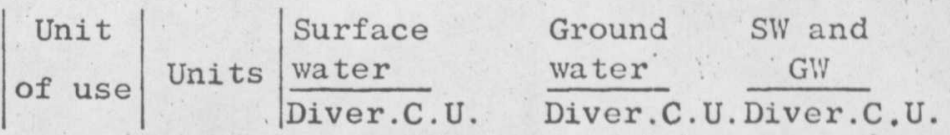



Water Nanagement and Legal Considerations (by the logical breakdown between surface and ground water, and as applicable in the basin area, the following items are to be discussed)

Water rights acquisition and administration*

Interstate compacts

Declared underground water basins

Court decress and adjudication

Transfer of place and method of use

* Breakdown of claimed rights for use of water will be furnished by Technical Div.

(Note: The above section to be written by legal staff of SEO. Much of the legal Nations, etc. set forth in the state-wide summary will be applicable

to all areas of the state and need not be repeated for each basin area. This section is intended to cover only those items directly applicable to the area itself, Example: Rio Grande Compact in the Rio Grande Basin). 


\section{Contents}

Page

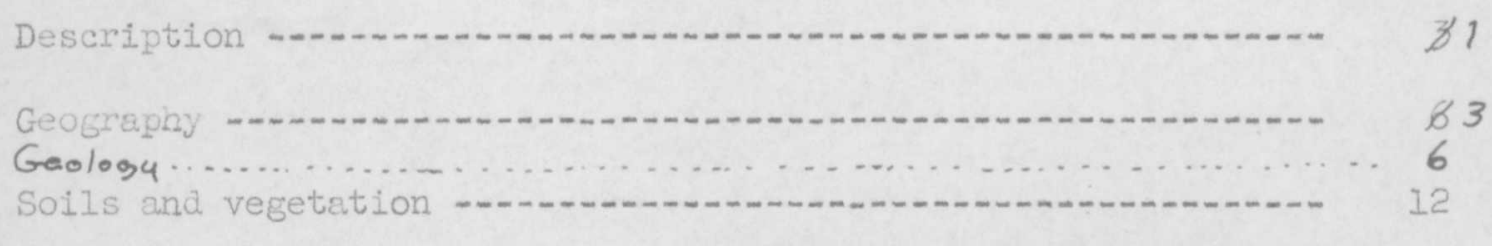

Hydrology

Climatology

Surf'ace water

Ground water

Selected references 
Figure 1.--Drainage basins of New Mexico

2.--Status of topographic mapping in New Mexico ........ 4

3.--Distribution of consolidated rocks in mountain ranges

of the southwestern closed drainage basins ...... 6

4.--Soils resources map of New Mexico 12

5.--Vegetative-type map of New Mexico 12

6.--The life zones of New Mexico 12

7.--Weather stations and climatologic divisions in

New Mexico _...

8.--Graphs showing average January and July temperatures

and average dates of last killing frost in spring and first killing frost in fall n............. 14

9.--Mean monthly temperatures at selected stations -n..- 14

10.--General availability of relatively fresh ground

water in New Mexico 20

11.--General occurrence of saline ground water in New Mexico

12.--General quality of shallow ground water in New Mexico

13.--Areas in New. Mexico in which ground-water studies have been made

14.--Areas of observation of water-level fluctuation in New Mexico 
Illustrations - Continued

Reference page

Figure 15.--Decline of ground-water level in the Animas basin, Hidalgo County, New Mexico, for the period $1948-60$ 16.--Decline of ground-water level in the Mimbres basin, Luna County, New Mexico, for the period $1940-60$ 
Tables

Page

Table 1.--Generalized stratigraphic section in the Southwestern

Closed Basins

8

evaporation, and wind movement

2.--Mean temperature, precipitation, at places in the

Southwestern Closed Basins

16

3.-- Summary of aging station records in Mimbres River

basin

18

4.--Ana.lysis of water sample from Mimbres River at Faywood

gaging station, Luna County, N. Mex.

19

5.--Analyses of water from wells in the Southwestern

Closed Basins

24

$\mathrm{v}$ 


\author{
Southwestern Closed Basins \\ By \\ Gene C. Doty
}

\title{
Description
}

The Southwestern Closed Basins are outlined on figure 1. Sub-basins Figure 1.-- (caption on next page) belongs near here

within this major drainage area are Mimbres, Animas, Playas, Wamel, San Luis, and Hachita. Counties and parts of counties included within the area are Luna, Hidalgo, Grant, Sierra, and Dona Ana. The larger cities and villages in the area are Deming in Luna County; Lordsburg in Hidalgo County; and Silver City in Grant County. 
Figure 1.--Drainage basins of New Mexico 
Geography

The Southwestern Closed Basins in New Mexico consist of six drainage areas. The Animas Basin, 9-1 on figure 1, is 2,170 sq mi (square miles); the Mimbres Basin, 9-2, is 4,515 sq. mi.; the Playas Basin, 9-3, is $470 \mathrm{sq} . \mathrm{mi}$; the Wamel Basin, 9-4, is $170 \mathrm{sq} . \mathrm{mi}$; the San Luis Basin, 9-5, is $165 \mathrm{sq}$. mi ; and the Hachita Basin, 9-6, is $930 \mathrm{sq} \cdot \mathrm{mi}$.

In most of the basins drainage does not follow a distinct channel. Runoff from precipitation spreads across the lowlands as sheet flow and teminates in shallow playa lakes. In the Animas Basin runoff collects in Animas Creek, in upper Animas Valley, and spreads northward across lower Animas Valley in a wide indistinct channel, which terminates in broad playas at the north end of the valley. The Mimbres River follows a distinct channel, generally southward, across about half the Mimbres Basin. Flood flow in the river usually terminates as sheet flow on the flats about 8 miles east of Deming, although unusually large munoffs may reach as far south as the Mexican border. The Mimbres River and its tributaries form the best defined drainage system in the Southwestern Closed Basins.

The Southwestem Closed Basins are within the Mexican Highland section of the Basin and Range Province and is an area of sharp topographic contrast. Mountain ranges parallel intermontane valleys or bolsons; altitude ranges from about 9,000 feet on the higher peaks in the northern part of the area to about 4,000 feet in the southern part of the Mimbres bolson near the Mexican border. 
All of the area within the Southwestern Closed Basins has been topographically mapped on a scale of 1:250,000 (200 foot-contour interval). About half the area has been mapped in detail on $7 \frac{1}{2}$ or 15 minute quadrangle maps ( $\mathrm{fig} \cdot 2$ ). Detailed maps are not available

Figure 2.--(caption on next page) belongs near here.

for about 60 percent of Luna County, about 30 percent of Hidalgo County and most of the southern "panhandle" section of Grant County. Topographic mapping is currentIy under way in all but about 14 percent of the area for which detailed maps are not available. 
Figure 2.--Status of topographic mapping in New Mexico 
Rocks that crop out in the Southwestern Closed Basins are of sedimentary, igneous, and metamorphic origin and range in age from Precambrian to Quatemary. No rocks of Triassic or Jurassic age crop out in the area. During late Cretaceous or early Tertiary time, intrusion and extrusion of igneous rocks was associated with early phases of orogenic folding and faulting. During Tertiary time volcanism covered most of the area with great thicknesses of flow rocks and blockfaulting uplifted the mountain masses. Uplift of the mountain areas has continued through Recent time. Table 1 is a generalized stratigraphic section in the Southwestern Closed Basins and figure 3 shows Figure 3.--(caption on next page) belongs near here. the distribution of the consolidated rocks.

The oldest sedimentary rocks which crop out in the Southwestern Closed Basins consist chiefly of marine limestones and shales and range in age from Cambrian through Cretaceous. The older sedimentary rocks crop out mostly in the mountains. Younger sedimentary rocks Within the basin range in age from Tertiary through Quaternary and crop out in the valiys and on fan slopes. The younger sedimentary rocks are unconsolidated - to consolidated gravels, sands, and clays, and mixtures of these perticle sizes derived from erosion of the older sedimentary and igneous rocks in the mountains. 
Figure 3.--Distribution of consolidated rocks in mountain ranges of the Southwestern Closed Basins. 
Igneous rocks cap, or comprise entirely, several mountains in the area and range in age and type from Precambrian granite to Quaternary basalt flows. Most of the igneous rocks are of Tertiary age and consist of extrusive and intrusive rocks of andesitic to rhyolitic composition. Quaternary basalt flows cover unconsolidated rocks of Tertiary and Quaternary age in parts of the Animas, Hachita, and Mimbres Basins .

Many mineral deposits are associated with the igneous intrusive rocks of the Southwestern Closed Basins. Base and precious metals, semiprecious gemstone, radioactive and other minerals have been prospected for in the area (Northrop, 1959). Copper was mined by Indians near Santa Rita prior to the Spanish exploration of the New -pen-

Mexico temritory, and today the pit copper mine at that locality is one of the larger mines of its type in the United States. Turquoise, also mined by the Indians, was produced from mines in Grant and Hidalgo Counties near the turn of the century, but is not presently mined in quantity. Manganese, tungsten, iron, lead, and zinc as well as gold and. silver are now, or have been, mined in the Southwestern Closed Basins. Fluorite has been mined at several localities in the area during war years and some radioactive minerals have been mined in the past decade. About a dozen prospect wells have been drilled in search of petroleum, but no producing wells have been completed in the area. 
The geology of the Southwestern Closed Basins has been the subject of numerous mining and general geology investigations. The most recent compilation of geologic mapping is Miscellaneous Geologic Investigations (Dane and Bachman, 1961)

Map I-34 p Preliminary geologic map of the southwest part of New Mexico, published by the U.S. Geological Survey. This map also includes a list of the more detailed maps from which it was compiled. The U.S. Geological Survey also published a geologic index map of New Mexico (795) which indicates areas included in available maps and reports. The most recent compilation of geologic information on the Southwestem Closed Basins. can be found in the guidebooks of the New Mexico Geological Society and Roswell Geological Society. Information in the Eleventh Field Conference Guidebook of the Roswell Geological Society (1958) and the Fourth Field. Conference Guidebook of the New Mexico Geological Society (1953) is pertinent to this area. 


\section{Soils and Vegetation}

Most of the Southwestern Closed Basins are covered by light- to medium-textured soil, thickest in the bolson plains and thinnest in and near the mountains. The soil is derived from sedimentary and igneous rocks eroded from the mountains and ranges widely in mineral composition. Alkaline minerals have accumulated in the playa.s and caliche (secondary carbonate) firmly cements soils locally. Wind-blown sand covers some areas. The solls resource map of New Mexico (fig. 4 ) Figure 4.--(caption on next pdge) belongs near here.

indicates the areas covered by general soil types. The lowland area of the Southwestern Closed Basins is semi-desert brush and grassland. Creosote bush, mesquite, yucca, and a variety of grasses cover this area in the lower Sonoran life zone. Woodland vegetation of pinyon, juniper, oak, and forest vegetation, mostly ponderosa pine, grow at the higher elevations in the upper Sonoran and Transition life zones. General areas of native vegetation are shown on the Vegetative type map of New Mexico (fig. 5).

\section{Figure $5 .--$ (caption on next page) belongs near here.}

The life zones of New Mexico are shown on figure 6. Most of the

Figure 6.--(caption on next page) belongs near here.

lowland areas are in the lower Sonoran life zone; the mountain slopes and peaks include upper Sonoran and Transition life zones. Most of the arable land in the southwestern Closed Basin area is in the lower Sonoran life zone. 
Figure 4.--Soil resource map of New Mexico

Figure 5.--Vegetative-type map of New Mexico

Figure 6.-FMap showing the life zones of New Mexico

, 


\section{Hydrology}

\section{Climatology}

Several weather stations are maintained in the Southwestern Closed Basins; see map of weather stations and climatologic divisions (fig. 7). The growing season in most of the area is from March or Figure $7 .-$-(caption on next page) belongs near here. early April through October, although April through September is commonly used for agricultural planting. (See fig. 8.) The mean monthly Figure 8.--(caption on next page) belongs near here. temperature at Silver City, Deming, and Animas is shown by bargraphs on figure 9.

Figure 9.--(caption on next page) belongs near here.

The mean temperature and precipitation by months for ten weather stations is tabulated in table 2; the tabulation also includes average figures for stations in the Southwestern Mountains and Southern Desert Divisions and the evaporation and total wind movement at Florida station. Most of the precipitation is during summer months when evaporation and plant evapotranspiration is high. Data is from records of the U.S. Weather Bureau. 
Figure 7.-Weather stations and climatologic divisions in New Mexico.

Figure 8.--Graphs showing average January and July temperatures and average dates of last killing frost in spring and fall.

Fisure 9.--Mean monthily temperatures at selected stations. 
Table 2.--Mean temperature, precipitation, evaporation, and wind movement at places in the Southwestern Closed Basins (U.S. Weather Bureau, 1959)

\begin{tabular}{|c|c|c|c|c|c|c|c|c|c|c|c|c|c|c|c|c|c|c|c|c|c|c|c|c|c|c|}
\hline \multirow[b]{2}{*}{ Station } & \multicolumn{2}{|c|}{ January } & \multicolumn{2}{|c|}{ February } & \multicolumn{2}{|c|}{ March } & \multicolumn{2}{|c|}{ April } & \multicolumn{2}{|c|}{ May } & \multicolumn{2}{|c|}{ June } & \multicolumn{2}{|c|}{ July } & \multicolumn{2}{|c|}{ August } & \multicolumn{2}{|c|}{ September } & \multicolumn{2}{|c|}{ October } & \multicolumn{2}{|c|}{ November } & \multicolumn{2}{|c|}{ December } & \multicolumn{2}{|c|}{ Annual } \\
\hline & 宊 & 造苋 & 禀 & 通 & $\dot{\mathrm{g}}$ & 道 & 蒠 & 通 & $\dot{\vec{c}}$ & $\underset{\dot{u}}{\dot{\omega}}$ & $\underset{\mathrm{E}}{\dot{\mathrm{E}}}$ & 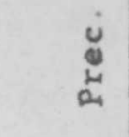 & $\dot{\tilde{G}}$ & 这 & $\stackrel{\dot{\rho}}{\dot{m}}$ & 怤 & 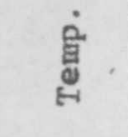 & 莒 & 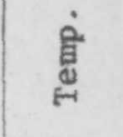 & ¿ّं & $\dot{\leftrightarrow}$ & 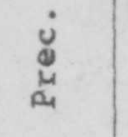 & $\dot{\mathrm{g}}$ & 遌 & $\dot{\mathrm{i}}$ & 递 \\
\hline Fort Bayard & 37.6 & .84 & 41 & 0.99 & 45.5 & 0.59 & 53.2 & 0.43 & 60.7 & 0.43 & 69.8 & 0.78 & 72.8 & 2.71 & 71.2 & 3.08 & 66.5 & 2.14 & 57.1 & 0.87 & 45.9 & 0.64 & 40.4 & 0.83 & 55.1 & 14.38 \\
\hline $\begin{array}{c}\text { Mimbres Ranger } \\
\text { Station }\end{array}$ & - & 1.20 & - & 1.17 & - & .84 & - & .54 & - & .49 & - & .92 & - & 2.95 & - & 3.28 & - & 2.12 & - & 1.20 & - & .75 & - & 1.11 & - & 16.57 \\
\hline Pinos Altos & - & 1.26 & - & 1.76 & - & 1.13 & - & .76 & - & .45 & - & 1.13 & - & 3.20 & - & 3.96 & - & 2.18 & - & 1.13 & - & .73 & - & 1.32 & - & 19.01 \\
\hline Silver City & - & 1.08 & - & 1.34 & - & .94 & - & .55 & - & .32 & - & .72 & - & 2.54 & - & 3.14 & - & 2.22 & - & 1.05 & - & .71 & - & 1.13 & - & 15.74 \\
\hline Animas & - & .59 & - & .63 & - & .54 & - & .26 & - & .15 & - & .56 & - & 1.80 & - & 2.10 & - & 1.22 & - & .64 & - & .42 & - & .62 & - & 9.53 \\
\hline Deming & 40.4 & .44 & 45.2 & .59 & 51.0 & .30 & 59.3 & .30 & 67.5 & .28 & 76.8 & .58 & 80.3 & 1.52 & 78.7 & 1.61 & 72.8 & 1.48 & 62.1 & .78 & 49.0 & .33 & 42.3 & .59 & 60.5 & 8.80 \\
\hline Gage & - & .59 & - & .80 & - & .41 & - & .29 & - & .20 & - & .44 & - & 1.39 & - & 1.76 & - & 1.56 & - & .78 & - & .42 & - & .71 & - & 9.35 \\
\hline Hachita & 40.9 & .52 & 45.2 & .70 & 50.7 & .45 & 58.7 & .25 & 66.6 & .17 & 75.5 & .43 & 78.4 & 1.74 & 76.7 & 2.25 & 71.5 & 1.14 & 61.3 & .78 & 49.2 & .37 & 42.7 & .69 & 59.8 & 9.49 \\
\hline Hermanas & - & .64 & - & .64 & - & .38 & - & .27 & - & .23 & - & .61 & $=$ & 1.83 & - & 1.98 & - & 1.67 & - & .72 & - & .31 & - & .74 & - & 10.02 \\
\hline Lordsburg & - & .77 & - & .95 & - & .58 & - & .37 & - & .14 & - & .50 & - & 1.42 & - & 2.02 & - & 1.24 & - & .69 & - & .52 & - & .68 & - & 9.88 \\
\hline $\begin{array}{l}\text { Southwestern } \\
\text { Mountains } \\
\text { Division (Avg.) } \\
\end{array}$ & - & .80 & - & .73 & - & .67 & - & .56 & - & .53 & - & .79 & - & 2.22 & - & 2.74 & - & 1.67 & - & .80 & - & .52 & - & .79 & - & 12.82 \\
\hline $\begin{array}{l}\text { Southern Desert } \\
\text { Division (Avg.) }\end{array}$ & - & .69 & - & .70 & - & .48 & - & .35 & - & .28 & - & .62 & - & 1.87 & - & 1.90 & - & 1.48 & - & .81 & - & .43 & - & .72 & - & 10.33 \\
\hline
\end{tabular}

Mean Evaporation, in inches, and total wind movement, in miles, 1960

(U.5. Weather Burean, 1960)

\begin{tabular}{|c|c|c|c|c|c|c|c|c|c|c|c|c|c|c|c|c|c|c|c|c|c|c|c|c|c|c|}
\hline & Evap. & Wind & Evap. & Wind & Evap. & Wind & Evap. & Wind & Evap. & Wind & Evap. & Wind & Evap. & wind & Evap. & Wind & Evap. & Wind & Evap. & Wind & Evap. & Wind & Evap. & Wind & Evap. & Wind \\
\hline lorida & 2.71 & 1499 & 4.34 & 2619 & 6.74 & 2745 & 9.45 & 2461 & 12.44 & 2455 & 14.06 & 1418 & 12.24 & 1151 & - & - & 8.33 & 1153 & 6.13 & 1380 & 4.38 & 12.07 & 3.34 & 1060 & - & - \\
\hline
\end{tabular}




\section{Surface water}

Records of four gaging stations on the Mimbres River drainage are summarized in table 3 . Surface water gaging stations are not maintained on the ephemeral streams in the Southwestern Closed Basins. Some measurements of streamflow in the lower reaches of the Mimbres were made by $W$. N. White about 1930 in connection with seepage run studies (White, 1931) and some older records of streamflow are reported in that publication, but the reliability of these records is doubtful. The total annual runoff in the Southwestern Closed Basins cannot be estimated accurately because drainage is erratic through ephemeral channels. Many canyons and draws have been dammed to store runoff in stock tanks. The annual virgin flow of the Mimbres River near Faywood is estimated to be 12,110 acre feet.

Water is diverted from the Mimbres for surface flooding of fields and pastureland, and a reservoir for storage and recreation has been constructed on Bear Canyon. The streamflow is not otherwise regulated by man-made structures and infrequent freshets spread over the lowlands as sheetflow. Flood damage from the Mimbres River and ephemeral streams in the Southwestern Closed Basins consist mostly of washing out of roads and drowning of crops. Floodwater in draws and arroyos is usually heavily charged with particles ranging in size from clay to boulders; no sediment stations are maintained in the area. The chemical quality of most surface water is good (table 4); only water that stands in the playa lakes dissolve large concentrations of minerals. 


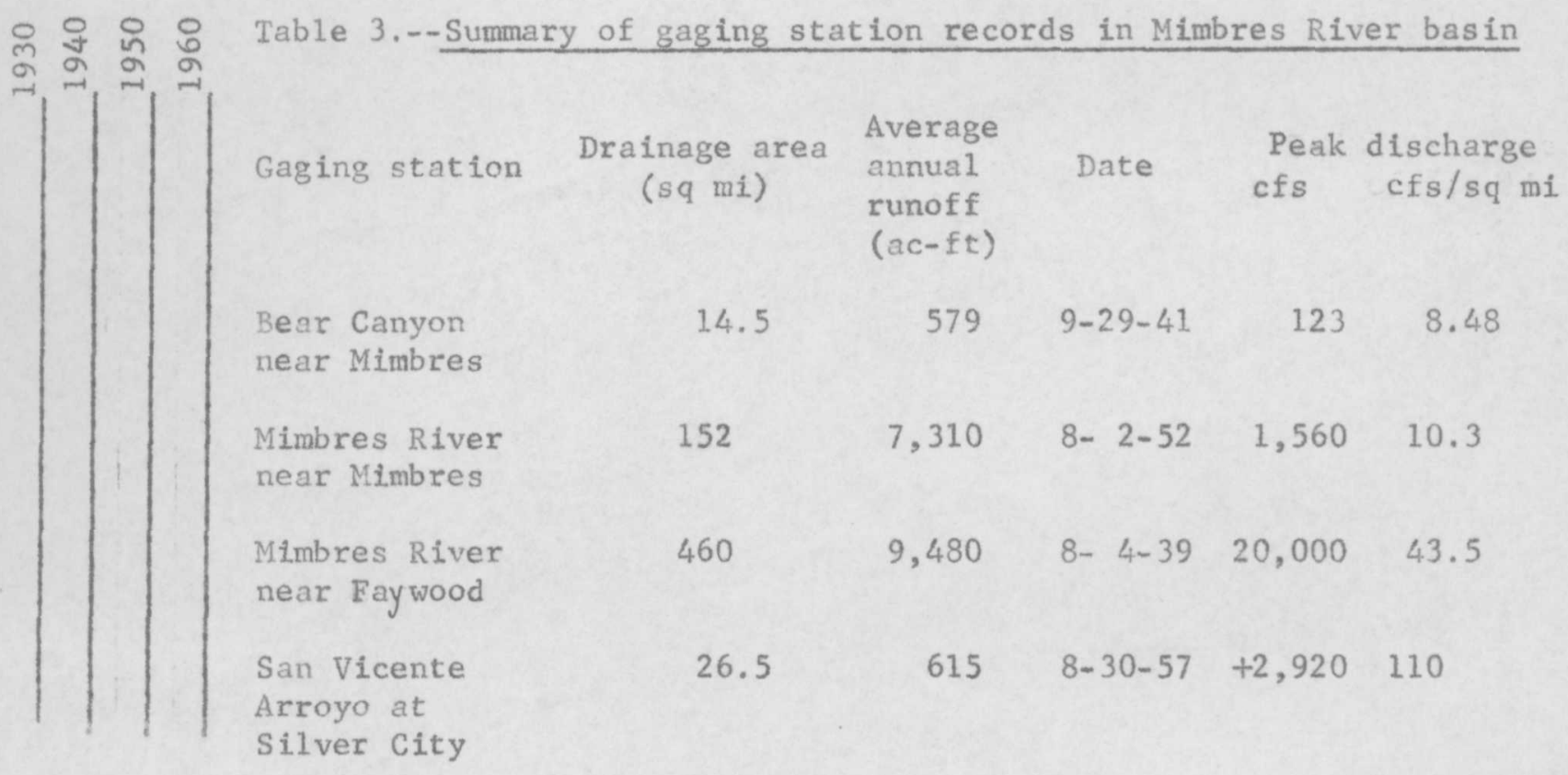


Table 4.--Analysis of water sample from Mimbres River at Faywood gaging station, Luna County, N. Mex.

Analyses by Geological Survey, United States Department of the Interior (parts per million)

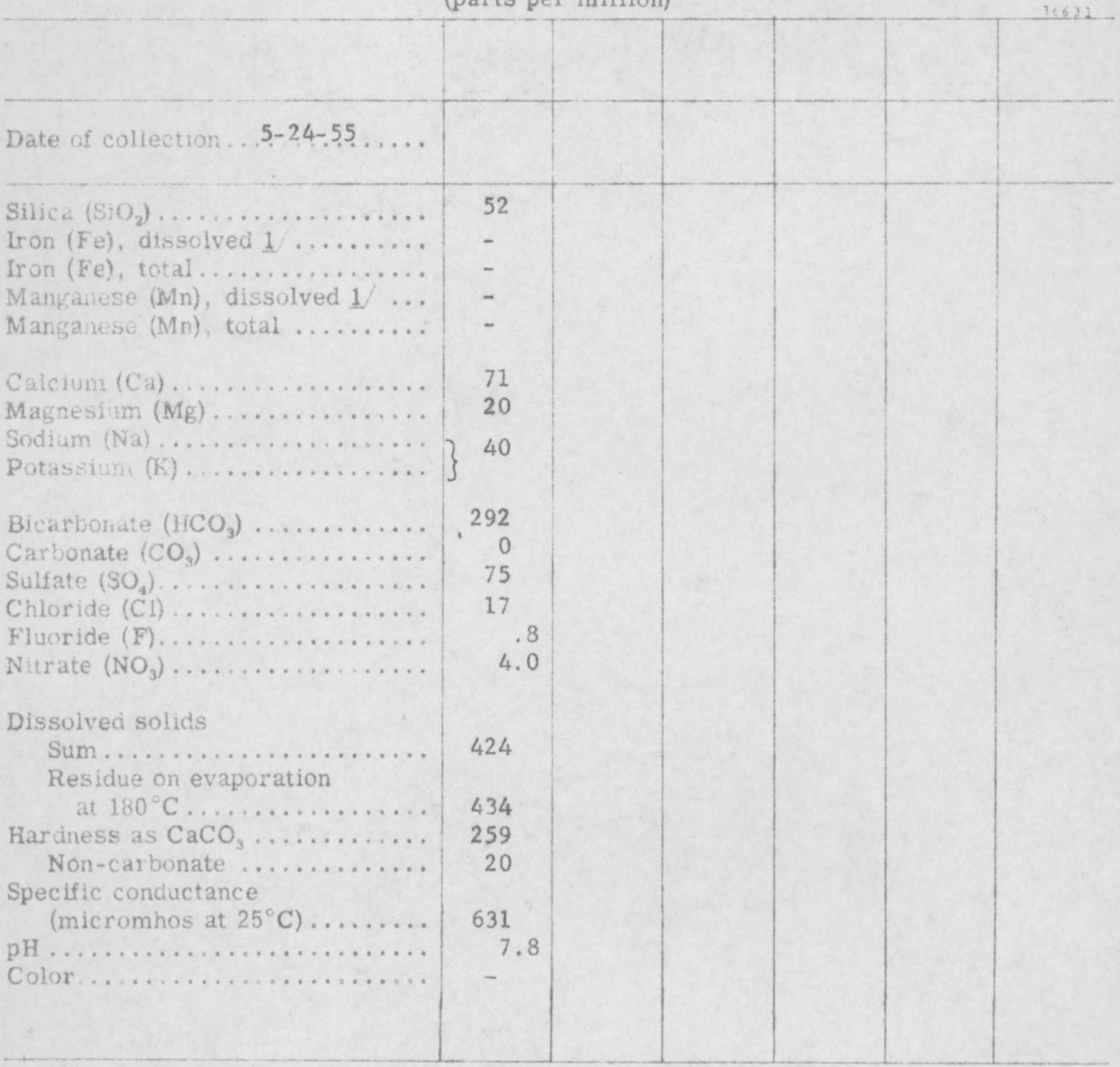

1 In solution at time of analysis. 
Most of the usable ground water in the Southwestern Closed Basins is contained in the Tertiary and Quaternary bolson deposits, although a few wells of smal1 to medium yield obtain water from older 1 imestone rocks near Silver City. Stock and domestic wells and springs also derive water from older rocks in the mountainous areas. Large quantities of water for irrigation, municipal, and industrial use are obtained from the bolson deposits. The bolson deposits consist of clay, sand, gravel, and mixtures of these particle sizes in irregular beds and lenses. The bolson deposits also include interbedded volcanic rocks locally. Thickness of the bolson deposits is more than 1,000 feet in places. Figure 10 shows areas in which sma11, moderate, and large supplies of Figure 10 (caption on next page) belongs near here. ground water are obtained from wells in New Mexico. The water in the bolson deposits is derived from precipitation on the drainage area; most recharge occurs along permeable stream beds such as the Mimbres River, and on the upland slopes of alluvial fans where coarse particles permit water to infiltrate easily. Runoff that reaches playas penetrates the underlying clay and silt beds very slowly and most of the water is evaporated. Ground water in most of the basins is moving toward a point of discharge, usually springs or seeps along playa lakes, but some ground water in deeply buried rocks may be stagnated. 
Figure 10.--General availability of relatively fresh ground water in New Mexico 
The amount of water in storage in the bolson deposits cannot be estimated accurately because the thickness of the deposits is not known and the deposits are hetergeneous mixtures of clay, sand, and gravel that range widely in storage capacity. The area of the bolson deposits in the Southwestern Closed Basins is approximately 5,600 square miles or $3,584,000$ acres. The volume of water in storage is about $179,200,000$ acre feet, if it is assumed that an average of 250 feet of saturated material underlies this area and that the average porosity of the material is 0.2 of the volume. Not all this volume of water, of course, is available to wells. Assuming an average annual precipitation of 10 inches per year, recharge to the ground water supply may be on the order of 1 percent of the precipitation over the total drainage area $(8,420$ square miles), or about 45,000 acre feet of water per year. The amount of water in storage in the older rocks is not estimated because of lack of information and the relatively small amount of water obtained from them. 
Water samples from selected wells in the Mimbres Basin and Animas Basin, are collected annually for chemical analysis. Ground water is of good quality in most of the Southwestern Closed Basins (figs. 11 and 12). Most of the water contains less than 1,000 ppm

Figure 11 (caption on next page) belongs near here.

Figure 12 (caption on next page) belongs near here.

(parts per million) total dissolved solids, but may contain more fluoride than is recommended for domestic use. The general quality of water may be inferred from the maps and the tabulation of chemical analyses. (see table 5.) Water from mines, and from wells near mines, is frequently of poor quality; highly mineralized water has been obtained from a few deep test wells in southeastern Luna County. The quality of water at depth in the bolson deposits may deteriorate to the extent that water quality, not economic pumping 1 ift, will be the 1 imiting factor in utilization of the water resources of the area. Little data is available on the quality of water at depths greater than 1,000 feet in the bolson deposits. 
Table 5.--Analyses of water from wells in the

\section{Southwestern Closed Basins}

Analyses by Geological Survey, United States Department of the Interior (parts per million)

Location

(Township, Range, Section)

$20 \mathrm{~s} ., 5 \mathrm{~W} .24 \mathrm{~s} ., 7 \mathrm{~W} \cdot 24 \mathrm{~s} ., 9 \mathrm{~W} .24 \mathrm{~s} ., 11 \mathrm{~W} .24 \mathrm{~s} ., 17 \mathrm{~W} \cdot 24 \mathrm{~s} ., 20 \mathrm{~W}$.

\begin{tabular}{l|l|l|l|l|l|l}
31 & 9 & 6 & 12 & 11 & 1 \\
\hline
\end{tabular}

Date of collection

$5-9-618-12-579-12-44$

$8-9-62 \quad 5-20-55 \quad 3--48$

Silica $\left(\mathrm{SiO}_{2}\right) \ldots \ldots \ldots \ldots \ldots \ldots \ldots$

Iron (Fe) dissolved $1, \ldots \ldots \ldots$.

Iron (qe) $\operatorname{tetal} \ldots \ldots \ldots \ldots \ldots \ldots . . . .$.

Manganese (Nin), dissolved 1 ....

Manganese (Mn), total ..........

Calcium $(\mathrm{C}$ a) $\ldots \ldots \ldots \ldots \ldots \ldots$.

Magnesium $(\mathrm{Mg}) \ldots \ldots \ldots \ldots \ldots \ldots$

Sodium $(\mathrm{Na}) \ldots \ldots \ldots \ldots \ldots \ldots \ldots$

Potassium $(\mathrm{K})$................

Bicarbonate $\left(\mathrm{HCO}_{3}\right) \ldots \ldots \ldots \ldots$.

Carbonate $\left(\mathrm{CO}_{3}\right) \ldots \ldots \ldots \ldots \ldots \ldots$

Sulfate $\left(\mathrm{SO}_{4}\right) \ldots \ldots \ldots \ldots \ldots \ldots \ldots$

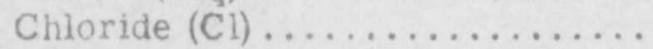

Fluoride $(F) \ldots \ldots \ldots \ldots \ldots \ldots \ldots$

Nitrate $\left(\mathrm{NO}_{3}\right) \ldots \ldots \ldots \ldots \ldots \ldots \ldots$

Dissolved solids

Sum...................

Residue on evaporation

at $180^{\circ} \mathrm{C} \ldots \ldots \ldots \ldots \ldots$

Hardness as $\mathrm{CaCO}_{3} \ldots \ldots \ldots \ldots$.

Non-carbonate ............. Specific conductance

(micromhos at $25^{\circ} \mathrm{C}$ ) ........

$\mathrm{pH}, \ldots \ldots \ldots \ldots \ldots \ldots \ldots \ldots \ldots \ldots \ldots$

Color......................

81

83

\begin{tabular}{|c|c|} 
& 22 \\
& \\
29 & 36 \\
7.7 & 6.6
\end{tabular}

31

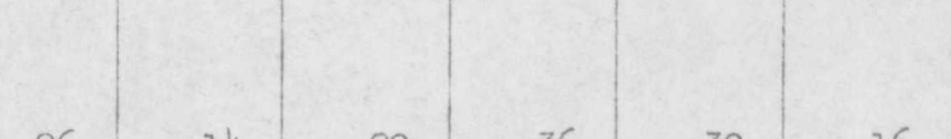

26
6.6

14

67

115

193

13

27

12

1.3

246

246
0

50

16

11

4.4

\section{7}

278

30

16

4.4

112

45

182

122

19

9

19

.6

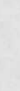

$\begin{array}{r}4 \\ 568 \\ \hline\end{array}$

179

232

0

86

14

11

-

2.8

3.1

2.8

\section{0}

$4 x$

2.9

.8
.6

19

109 
Table 5.--Analyses of water from wells in the Southwestern Closed Basins-Continued

Analyses by Geological Survey, United States Department of the Interior (parts per million)

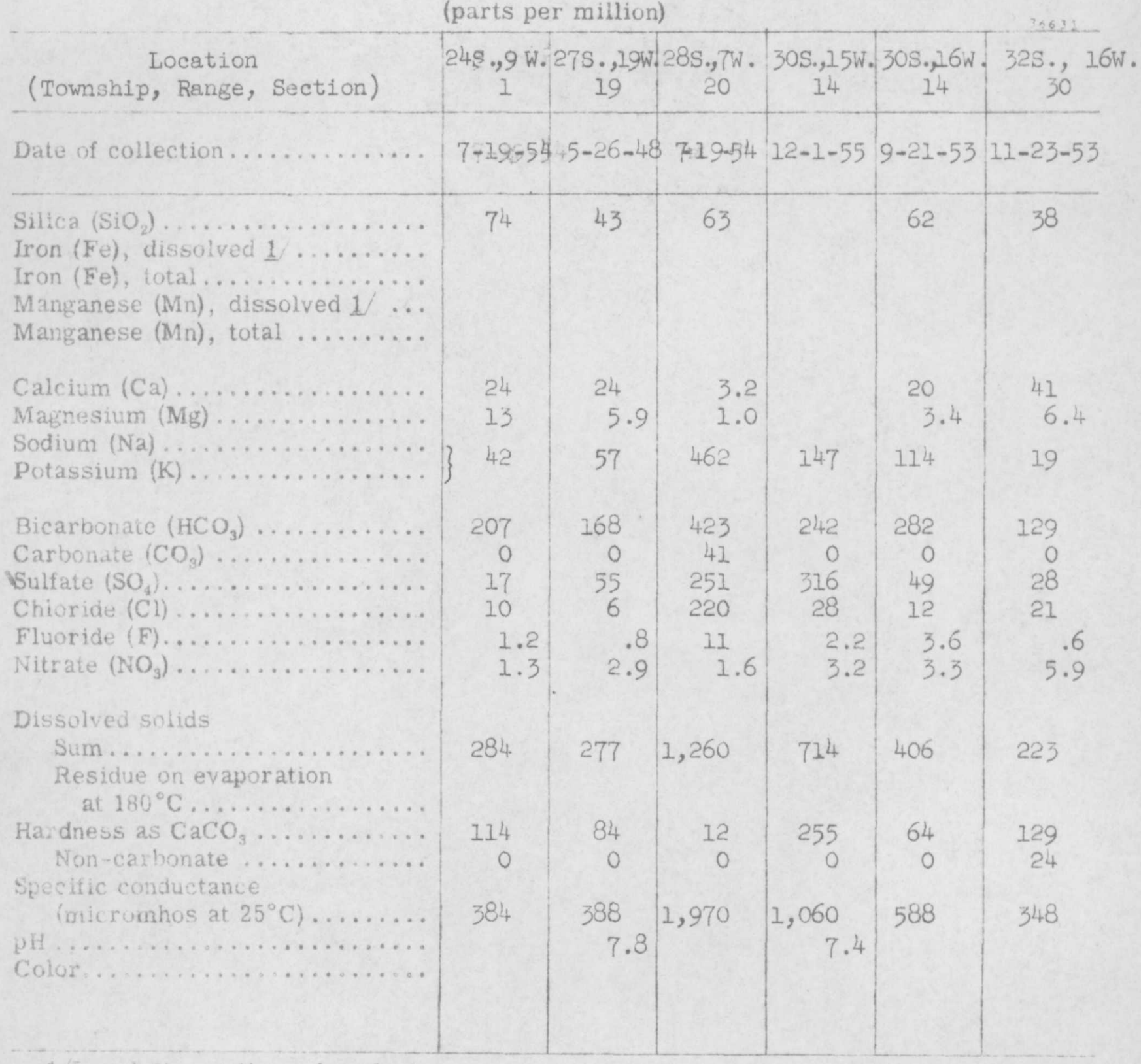

$1 /$ In solution at time of analysis. 
Figure 11.--General occurrence of saline ground water in New Mexico

Figure 12.--General quality of shallow ground water in New Mexico 
Most of the area of the Southwestern Closed Basins was included in the ground water studies made about 1910 and published as U.S. Geological Survey Water-Supply Paper 422 and Bulletin 618. Reports of more recent investigations include State Engineer Technical
(Meeder, 1957)
(Do+y, 1960)
(Tranger-and Herrick, 1962)

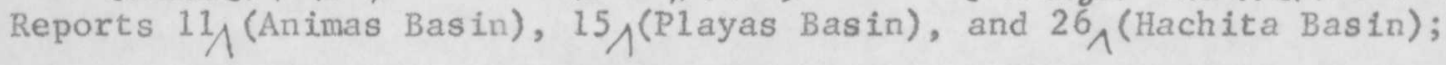
studies current1y under way by the U.S. Geological Survey, but not yet published, include Grant County and southern Luna County. Figure 13 shows

Figure 13 (caption on next page) belongs near here.

the areas in New Mexico in which ground-water studies have been made. The areas in which periodic measurements of water levels in observation wells are made are shown on figure 14. The measurements of

Figure 14 (caption on next page) belongs near here.

water level are reported in the series "Water levels and artesian pressures in wells in the United States, southwestern states," by the U.S. Geological Survey and in the Technical Report series, through 1960, and unnumbered basic data reports, after 1960 , by the New Mexico State Engineer Office.

Figures 15 and 16 show the decline of ground-water levels in the

Figure 15 (caption on next page) belongs near here.

Figure 16 (caption on next page) belongs near here.

Animas basin for the period 1948-60 and in the Mimbres basin for the period 1940-60, respectively. 
Figure 13.--Areas in New Mexico in which ground-water studies have been made.

Figure 14.--Areas of observation of water-level fluctation in New Mexico.

Figure 15.--Deciline of ground-water level in the Antmas basin, Hidalgo County, New Mexico, for the period 1948-60.

Figure 16.--Decline of ground-water level in the Mimbres basin, Luna County, New Mexico, for the period 1940-60. 
Boardman, Leona, Brown, Annabel, and Bone, A. N., 1956, Geologic map index of New Mexico: U.S. Geol. Survey.

Dane, C. H., and Bachman, G. O., 1961, Preliminary geologic map of the southwestern part of New Mexico: U.S. Geol. Survey Misc. Geol. Inv. Map I-344.

Darton, N. H., 1916, Geology and underground water of Luna County, New Mexico: U.S. Geo1. Survey Bu11. 618, 188 p., 28 illus.

Doty, G. C., 1960, Reconnaissance of ground water in Playas Valley, Hidalgo County, New Mexico: N. Mex. State Engineer Tech. Rept. 15, 40 p., 10 illus.

Fenneman, N. M., 1931, Physiography of western United States: McGraw-H111, New York, 534 p.

New Mexico Geological Society, 1953, Guidebook of southwestern New Mexico, New Mexico Geo1. Soc, 4th Field Conf., 1953: 153 p.

Northrop, S. A., 1959, Minerals of New Mexico: Albuquerque, N. Mex., University of New Mexico Press, 665 p.

Reeder, H. O., 1957, Ground water in Animas Valley, Hidalgo County, New Mexico: N. Mex. State Engineer Tech. Rept. 11, 101 p., 27 illus.

Roswe11 Geological Society, 1958, Guidebook of the Hatchet Mountains and the Cooks Range-Florida Mountain areas, Roswel1 Geol. Soc. $11_{\lambda}^{\text {th }}$ Field Conf., 1958: 140 p. 


\section{Selected references - continued}

Schwennesen, A. T., 1918, Ground water in the Animas, Playas,

Hachita, and San Luis Basins, New Mexico: U.S. Geol. Survey

Water-Supply Paper 422, 152 p., 26 illus.

Trauger, F. D., and Herrick, E. H., 1962, Ground water in Central Hachita

Valley northeast of the Big Hatchet Mountains, Hidalgo County,

New Mexico: N. Mex. State Engineer Tech. Rept. 26, 21 p., 3 illus.

U.S. Weather Bureau, 1959, Climates of the States- New Mexico:

Climatography of the United States, No. 60-29.

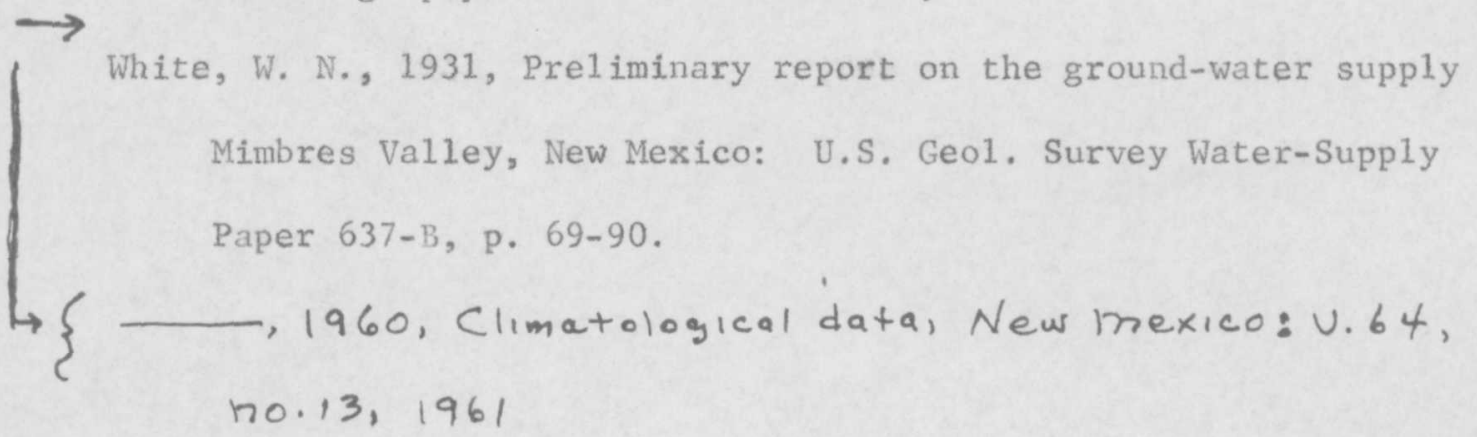




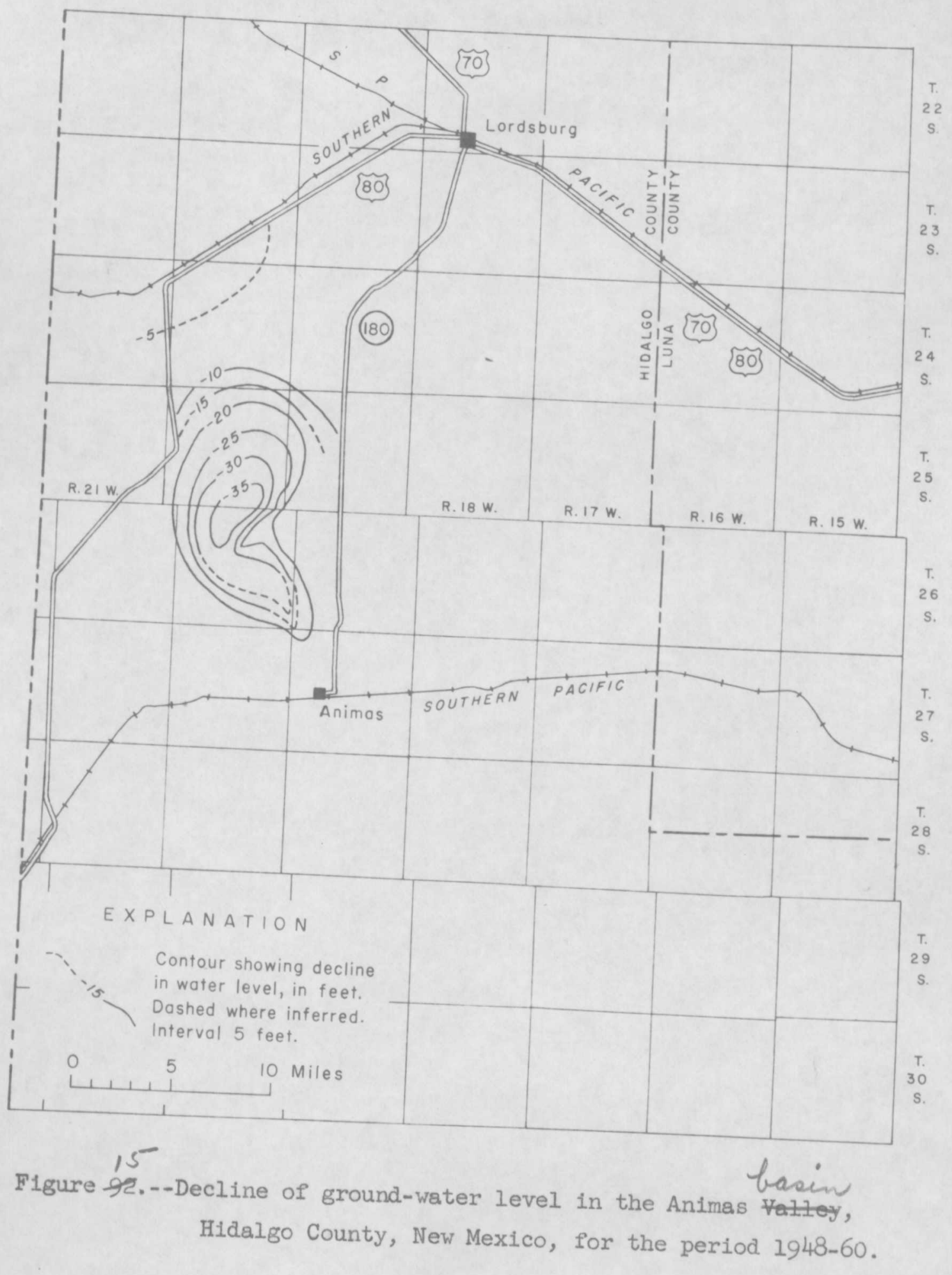

$28 c$ 


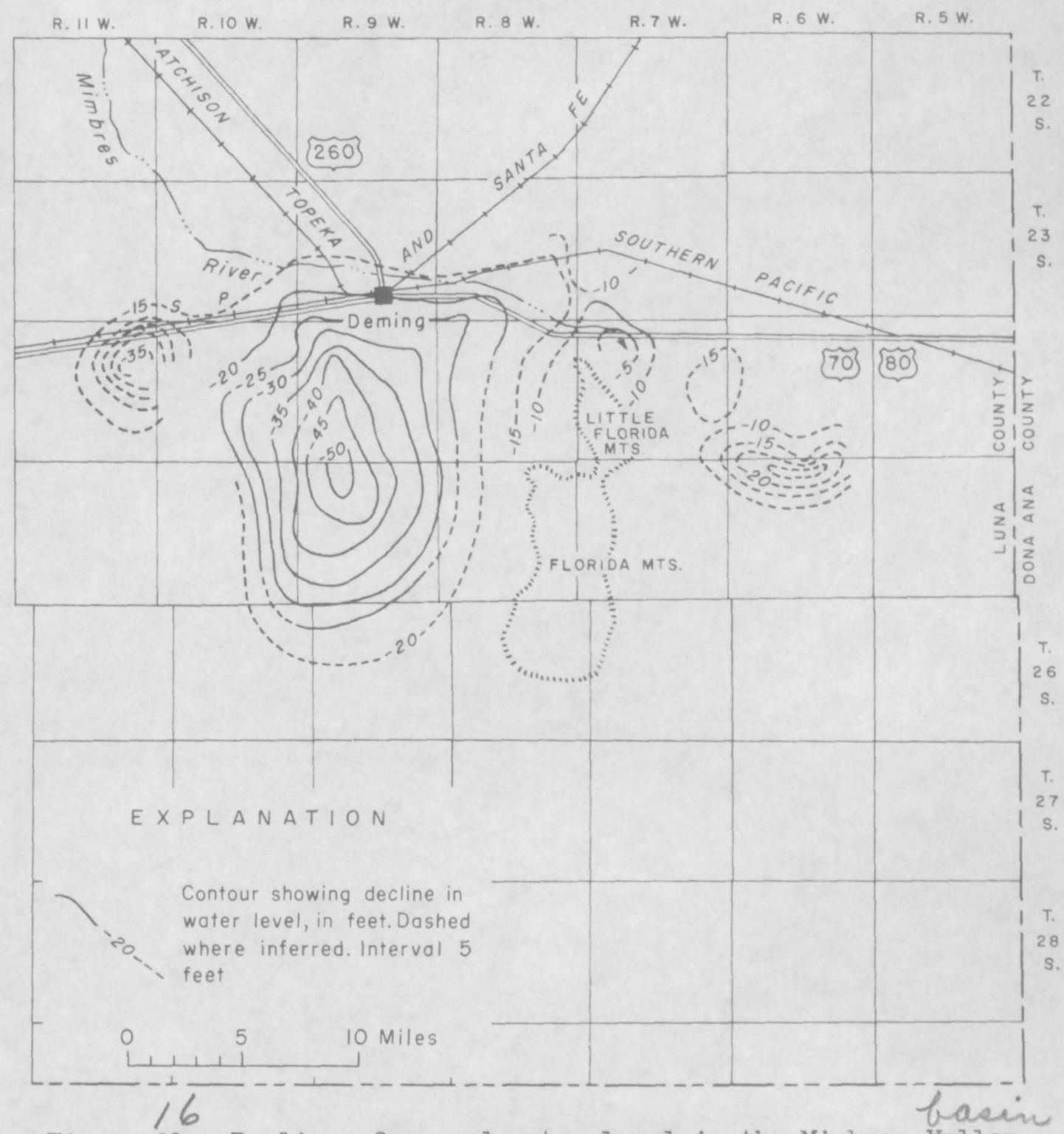

Figure 91.--Decline of ground-water level in the Mimbres Valley, Luna County, Nèw Mexico, for the period 1940-60. 
Table 1.-- Generalized stratigraphic section in the Southwestern Closed Basins, New Mexico

\begin{tabular}{|c|c|c|c|c|c|}
\hline System & $\begin{array}{c}\text { Stratigraphic } \\
\text { Unit }\end{array}$ & $\begin{array}{l}\text { Thickness } \\
(\text { fcet })\end{array}$ & Distribution & Physical prope ties & Water-bearing characteristics \\
\hline \multirow[t]{2}{*}{ Quaternary } & $\begin{array}{l}\text { Stream } \\
\text { channel } \\
\text { alluvium } \\
\text { and wind- } \\
\text { blown de- } \\
\text { posits. }\end{array}$ & $0,100 \pm$ & $\begin{array}{l}\text { In all major valleys } \\
\text { and in most minor } \\
\text { tributaries. }\end{array}$ & $\begin{array}{l}\text { Unconsolidated clay, } \\
\text { silt, sand, and } \\
\text { gravel; generally } \\
\text { poorly sorted; varied } \\
\text { composition. }\end{array}$ & $\begin{array}{l}\text { Poor to excellent, depending on the coarseness } \\
\text { and degree of sorting. }\end{array}$ \\
\hline & Basalt & $0_{n}^{t} 100 \pm$ & $\begin{array}{l}\text { In Animas, Hachita, and } \\
\text { Mimbres Valleys and } \\
\text { West Potrillo } \\
\text { Mountains. }\end{array}$ & $\begin{array}{l}\text { Dense to highly } \\
\text { scoriaceous and } \\
\text { broken flows of } \\
\text { basalt. }\end{array}$ & $\begin{array}{l}\text { Unknown but could produce large quantities } \\
\text { of water under favorable circumstances. }\end{array}$ \\
\hline $\begin{array}{l}\text { Quaternary } \\
\text { and } \\
\text { Tertiary }\end{array}$ & $\begin{array}{l}\text { Bolson de- } \\
\text { posits, fan } \\
\text { and terrace } \\
\text { gravels, } \\
\text { older } \\
\text { alluvial } \\
\text { material, } \\
\text { Santa Fe } \\
\text { Group, Gila } \\
\text { conglomerate } \\
\text { and local } \\
\text { Interbeds } \\
\text { of rhyolite } \\
\text { and basalt }\end{array}$ & $\begin{array}{l}0 \text { to several } \\
\text { thousand }\end{array}$ & $\begin{array}{l}\text { Intermontane basins } \\
\text { and fan slopes. }\end{array}$ & $\begin{array}{l}\text { Unconsolidated to } \\
\text { locally, we1l- } \\
\text { consolidated beds } \\
\text { and lenses of clay, } \\
\text { silt, sand, and } \\
\text { gravel, and mixtures } \\
\text { of these particle } \\
\text { sizes. }\end{array}$ & $\begin{array}{l}\text { Poor to excellent; yields range up to } 2,000 \mathrm{gpm} \\
\text { in some wells in southern Luna County. The } \\
\text { bolson deposits are the major aquifer in the } \\
\text { Southwestern Closed Basin area. }\end{array}$ \\
\hline Tertiary & $\begin{array}{l}\text { Igneous } \\
\text { rocks, } \\
\text { Intrusive } \\
\text { and extru- } \\
\text { sive rocks } \\
\text { of varied } \\
\text { composition } \\
\text { including } \\
\text { Datil and } \\
\text { Rubio Peak } \\
\text { Formations }\end{array}$ & $\begin{array}{l}\text { Ranges } \\
\text { widely to } \\
\text { several } \\
\text { thousand. } \\
\text { Maximum es- } \\
\text { timated } \\
8,000 \text { to } \\
10,000\end{array}$ & $\begin{array}{l}\text { Mountains and hills } \\
\text { throughout the area. }\end{array}$ & $\begin{array}{l}\text { Flows and intrusive } \\
\text { rocks ranging from } \\
\text { basaltic to rhyolitic } \\
\text { composition; dense } \\
\text { to tuffaceous flow } \\
\text { rocks including } \\
\text { agglomerates, } \\
\text { brecciated pyroclas- } \\
\text { tics, and welded } \\
\text { tuffs. }\end{array}$ & $\begin{array}{l}\text { Generally poor; yields small quantities of water } \\
\text { to stock wells and springs; fractured flows } \\
\text { may transmit large quantities of water under } \\
\text { favorable circumstances. }\end{array}$ \\
\hline
\end{tabular}


Table 1.--Generalized stratigraphic section in the Southwestern Closed Basins, New Mexico - Continued

\begin{tabular}{|c|c|c|c|c|c|}
\hline System & $\begin{array}{c}\text { Stratigraphic } \\
\text { Unit }\end{array}$ & $\begin{array}{l}\text { Thickness } \\
\text { (feet) }\end{array}$ & Distribution & Physical properties & Water-bearing characteristics \\
\hline $\begin{array}{l}\text { Tertiary - } \\
\text { Continued } \\
-.-.--\end{array}$ & $\begin{array}{l}\text { Fanglomerate } \\
\text { and lime- } \\
\text { stone con- } \\
\text { glomerate }\end{array}$ & $100 \pm$ & $\begin{array}{l}\text { Mountains and hills in } \\
\text { Cooks Range, Florida } \\
\text { and Big Hatchet } \\
\text { Mountains. }\end{array}$ & $\begin{array}{l}\text { Conglomerates and beds } \\
\text { of clay, silt, sand, } \\
\text { and gravel commonly } \\
\text { well-indurated; may } \\
\text { be interbedded with } \\
\text { volcanic rocks. }\end{array}$ & Unknown, but probab1y poor. \\
\hline $\begin{array}{l}\text { Tertiary- } \\
\text { Cretaceous }\end{array}$ & $\begin{array}{l}\text { Igneous } \\
\text { rocks, in- } \\
\text { trusive and } \\
\text { extrusive } \\
\text { rocks of an- } \\
\text { desite to } \\
\text { rhyolite } \\
\text { composition }\end{array}$ & $\begin{array}{l}\text { Ranges } \\
\text { widely }\end{array}$ & $\begin{array}{l}\text { Mountains and hills in } \\
\text { Pyramid and Little } \\
\text { Hatchet Mountains and } \\
\text { Coyote Hills. }\end{array}$ & $\begin{array}{l}\text { Syenodiorite, grano- } \\
\text { diorite and granite } \\
\text { sills and laccoliths, } \\
\text { andesite-latite- } \\
\text { rhyolite flows. } \\
\text { Dense to tuffaceous. }\end{array}$ & Unknown, but probab1y poor. \\
\hline Cretaceous & $\begin{array}{l}\text { Undiffer- } \\
\text { entiated }\end{array}$ & $\begin{array}{l}\text { Ranges to } \\
15,000 \pm\end{array}$ & $\begin{array}{l}\text { Cooks Range, Florida, } \\
\text { Animas, Peloncillo, } \\
\text { Hatchet and Pinos } \\
\text { Altos Mountains, } \\
\text { Coyote Hills and } \\
\text { Sierra Rica. }\end{array}$ & $\begin{array}{l}\text { Sandstone, quartzite, } \\
\text { shale, and limestone. }\end{array}$ & Unknown. \\
\hline $\begin{array}{l}\text { Permian } \\
\text { Pennsylvanian } \\
\text { Mississippian }\end{array}$ & $\begin{array}{l}\text { Undiffer- } \\
\text { an entiated } \\
\text { an }\end{array}$ & $\begin{array}{l}\text { Ranges to } \\
9,000 \pm\end{array}$ & $\begin{array}{l}\text { Black Range, Cooks } \\
\text { Range, Florida, Tres } \\
\text { Hermanas, Cedar, } \\
\text { Hatchet, Animas, and } \\
\text { Pinos A1tos, } \\
\text { Peloncillo Mountains, } \\
\text { and Sierra Rica. }\end{array}$ & $\begin{array}{l}\text { Limestone, dolomite, } \\
\text { shale, and sandstone. }\end{array}$ & $\begin{array}{l}\text { Generally unknown and suspected to be poor; } \\
\text { however, Iimestone near Silver City yields } \\
\text { as much as } 150 \mathrm{gpm} \text { and yields of } 500 \mathrm{gpm} \\
\text { from fractured limestone may be possible in } \\
\text { some areas. }\end{array}$ \\
\hline Devonian & $\begin{array}{l}\text { Percha } \\
\text { Formation }\end{array}$ & $300 \pm$ & $\begin{array}{l}\text { Pinos Altos, Florida, } \\
\text { Cedar, Hatchet, and } \\
\text { Peloncillo Mountains. }\end{array}$ & $\begin{array}{l}\text { Shale and shaly } \\
\text { limestone. }\end{array}$ & Poor. \\
\hline $\begin{array}{l}\text { Silurian, } \\
\text { Ordovician, } \\
\text { and } \\
\text { Cambrian }\end{array}$ & $\begin{array}{l}\text { Undiffer- } \\
\text { entiated }\end{array}$ & $1,500 \pm$ & $\begin{array}{l}\text { Black Range, Cooks } \\
\text { Range, Florida, Pinos } \\
\text { A1tos, Victorio, } \\
\text { Cedar, Hatchet, } \\
\text { Animas, and Peloncillo } \\
\text { Mountains and Sierra } \\
\text { Rica. }\end{array}$ & $\begin{array}{l}\text { Cherty dolomite, dolo- } \\
\text { mitic } 1 \text { imestone, } \\
\text { massive to thin- } \\
\text { bedded limestone, } \\
\text { glauconitic and } \\
\text { hematitic sandstone } \\
\text { and quartzite. }\end{array}$ & $\begin{array}{l}\text { Large yields possible from fractured rocks in } \\
\text { some areas; wells near Silver City produce } \\
400 \mathrm{gpm} \text { from Paleozoic limestone. }\end{array}$ \\
\hline
\end{tabular}


Table 1,--Generalized stratigraphic section in the Southwestern Closed Basins, New Mexico - Concluded

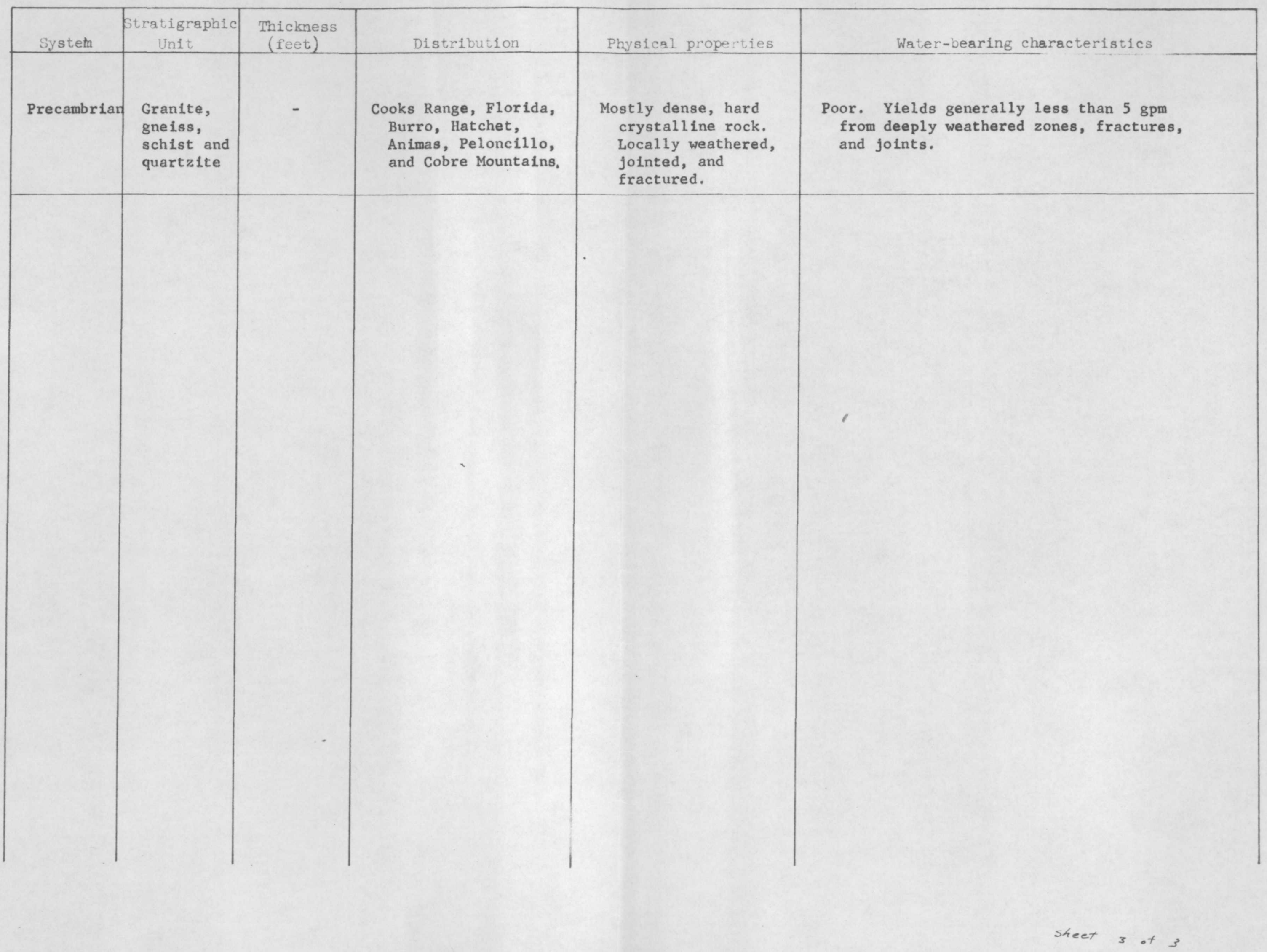




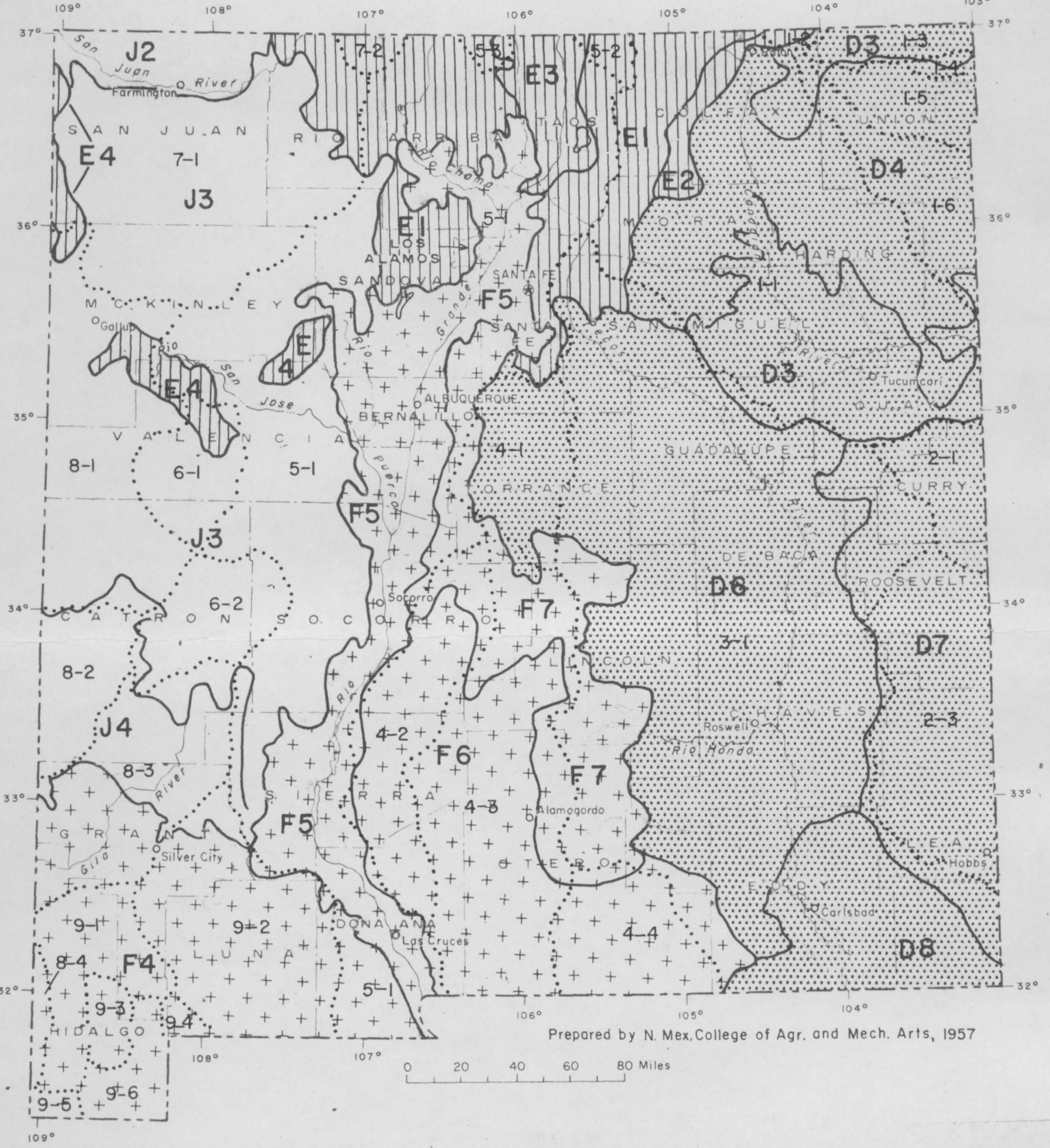

\section{$\ldots$}

$D_{3}$ Generally shallow solls in steeply rolling and rough broken areas. Moderately deep and deep solls in valley bottoms and alJuvial fans.

$D_{4} \quad$ Largely moderately deep to deep, medium to heavy-textured soils interspersed with some areas of shallow solls; generally gently rolling topography.

$D_{6}$ Dominantly moderately deep to deep, mediumtextured solls with rolling topography, interspersed with areas of shallow solls and deep sandy solls with dune-like topography.

$D_{7}$ Generally loose sandy solls with dune-like topography east of Pecos river, interspersed with areas of shallow to moderately deep, medium to heavy-textured sills west of Pecos river.

$D_{8}$ Similar to D-7, east of Pecos river, interspersed with areas of shallow to moderately deep, medium-textured solls west of Pecos river.

$\mathrm{E}_{1}$ Largely shallow to moderately deep, light to medium-textured soils with rolling to mountainous topography. Generally shallow solls on escarpments and mountainous areas.
$\mathrm{F}_{4}$ Generally light to medium-textured, deep and shallow solls with rolling topography, interspersed w1th low mountains. Dominantly shallow solls and rock outcrops in mountainous areas.

$F_{5} \quad$ Large areas of light to medium-textured, shallow to moderately deep solls with gentle to moderate slopes.

$F_{6}$ Mesas, benchlands, and mountain slopes. Largely light to medium-textured, shallow to moderately deep solls on mesas and benchlands, and gravelly shallow solls on mountain slopes and foothills.

$F_{7} \quad$ Largely mountain ranges and foothill slopes. Dominantly medium-textured solls on mountailn slopes, and moderately deep to deep soils on foothill slopes.

$\mathrm{J}_{2}$ Dominantly medium-textured, shallow solls on steep slopes. Medium-textured moderately steep slopes. Medium-textured moderately
deep soils on sloping plains, and dissected mesas; and medium to heavy-textured deep solls in valleys.

$\mathrm{J}_{3} \quad$ Largely medium-textured, moderatedy deep to shallow solls interspersed w1th areas of lighttextured solls. Generally rolling topography with steep slopes in mountainous areas.

$\mathrm{J}_{4} \quad$ Generally mountainous shallow solls interspersed with rock outcrops and small areas of moderately deep solls. Generally mountainous topography.

$$
\because 2-1:
$$




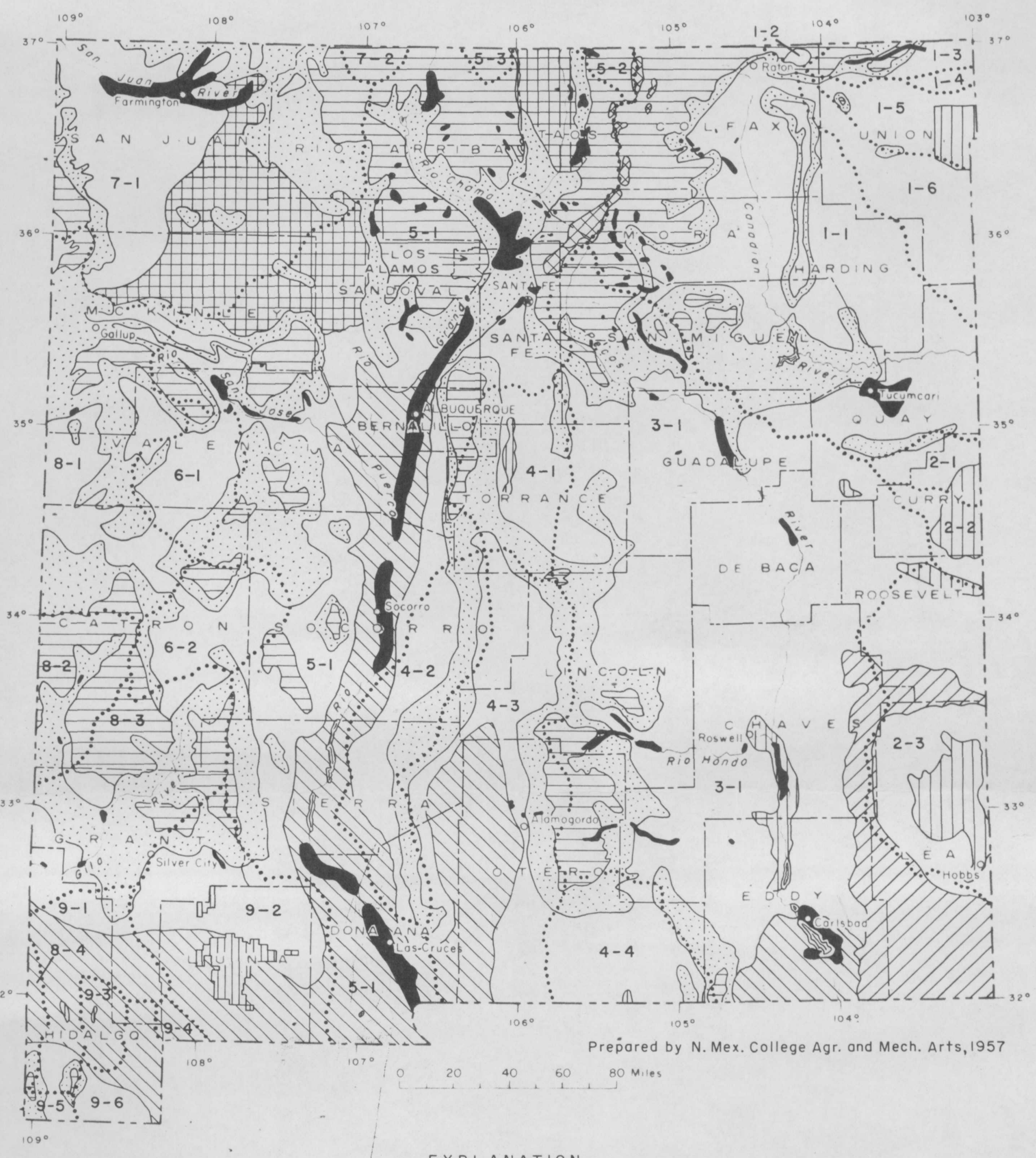

EXPLANATION

M Semi-desert brush

$\square$ Grassland

C/ shinnery

\#ig sagebrush

$\therefore$ Woodland $\otimes$ Tundra

Irrigated lands with water sources from surface water only or from surface water supplemented by pumping of ground water

प1D Irrigated lands with water source entirely from pumped or artesian ground water
Figume Lakes and reservoirs 

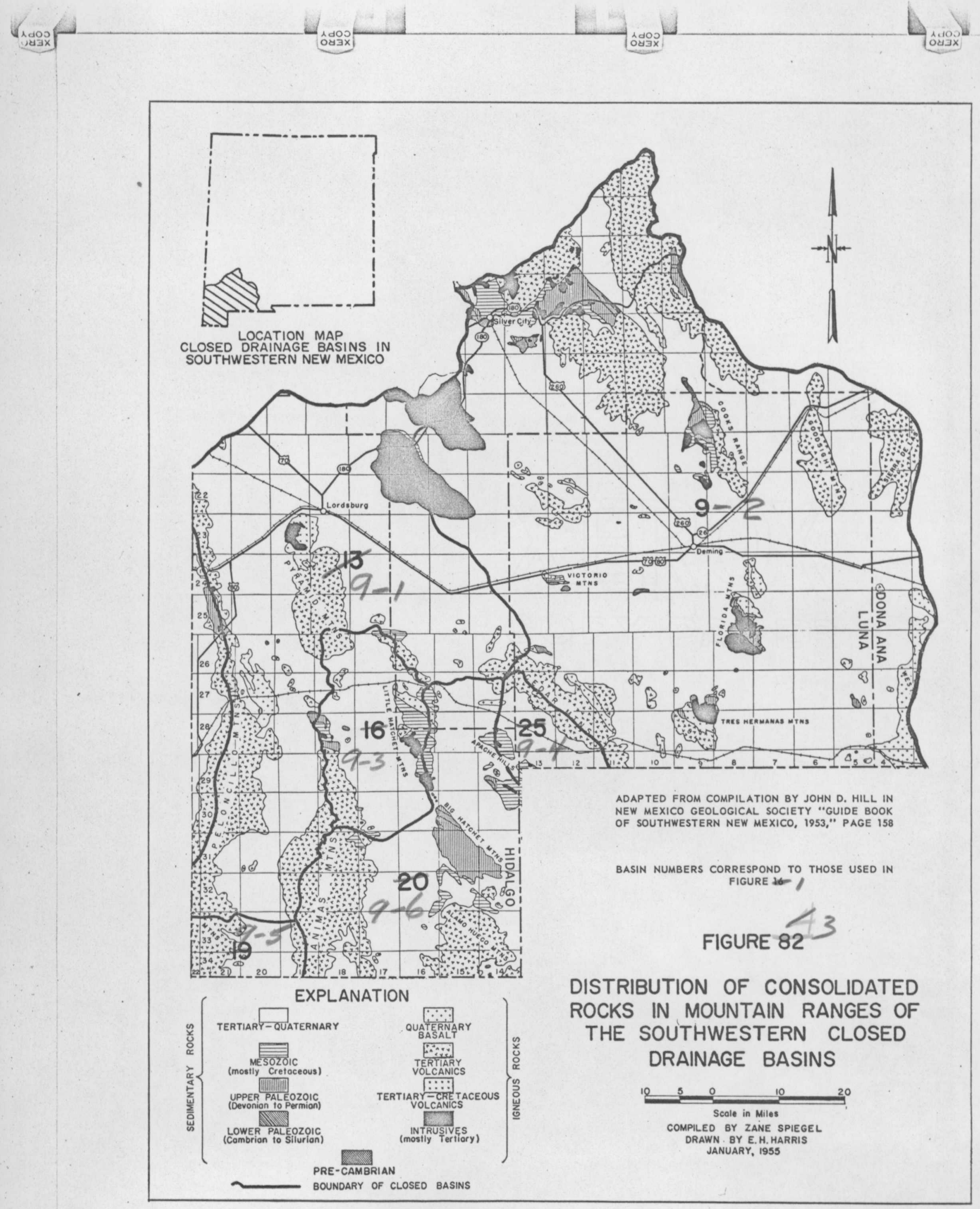

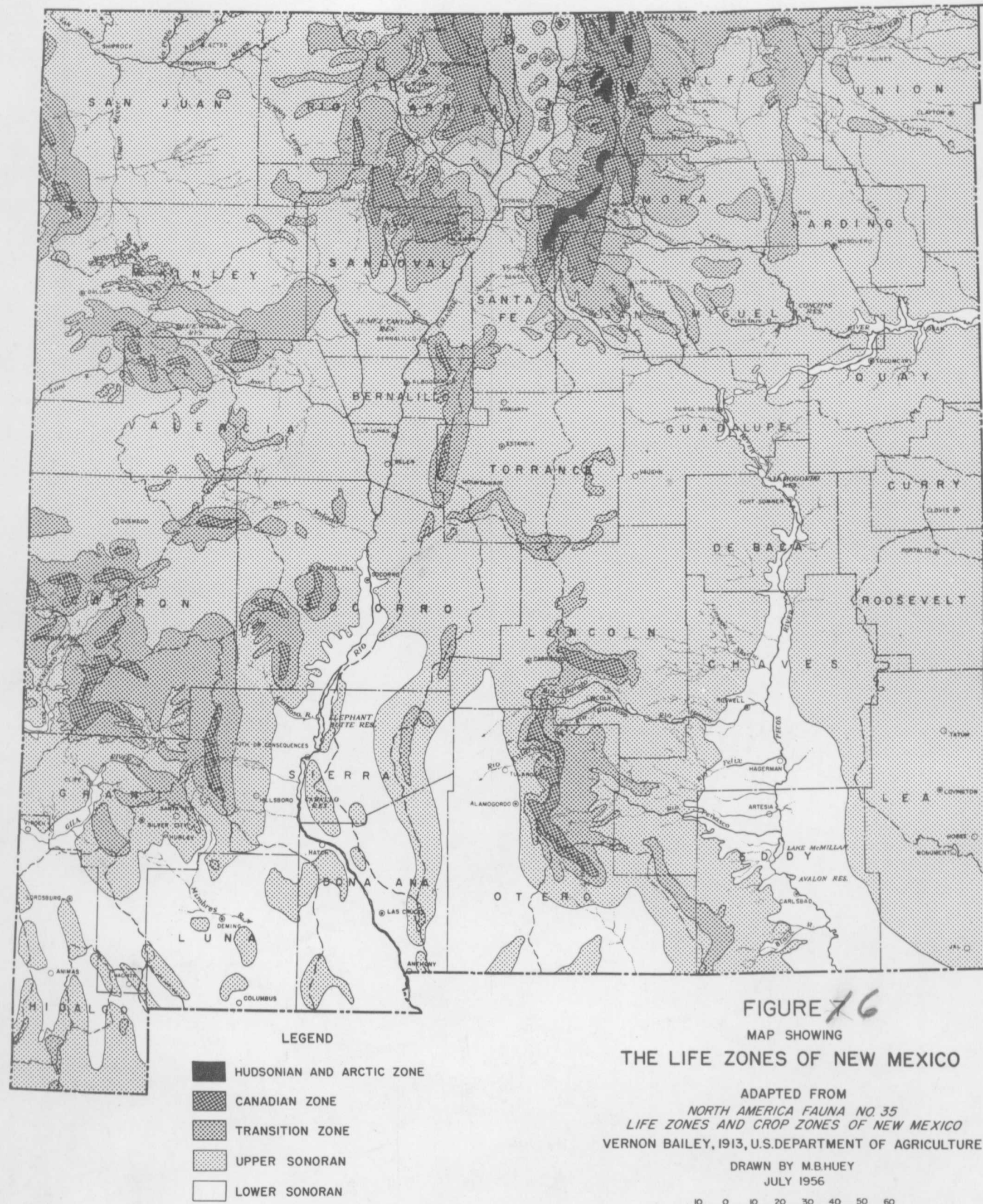


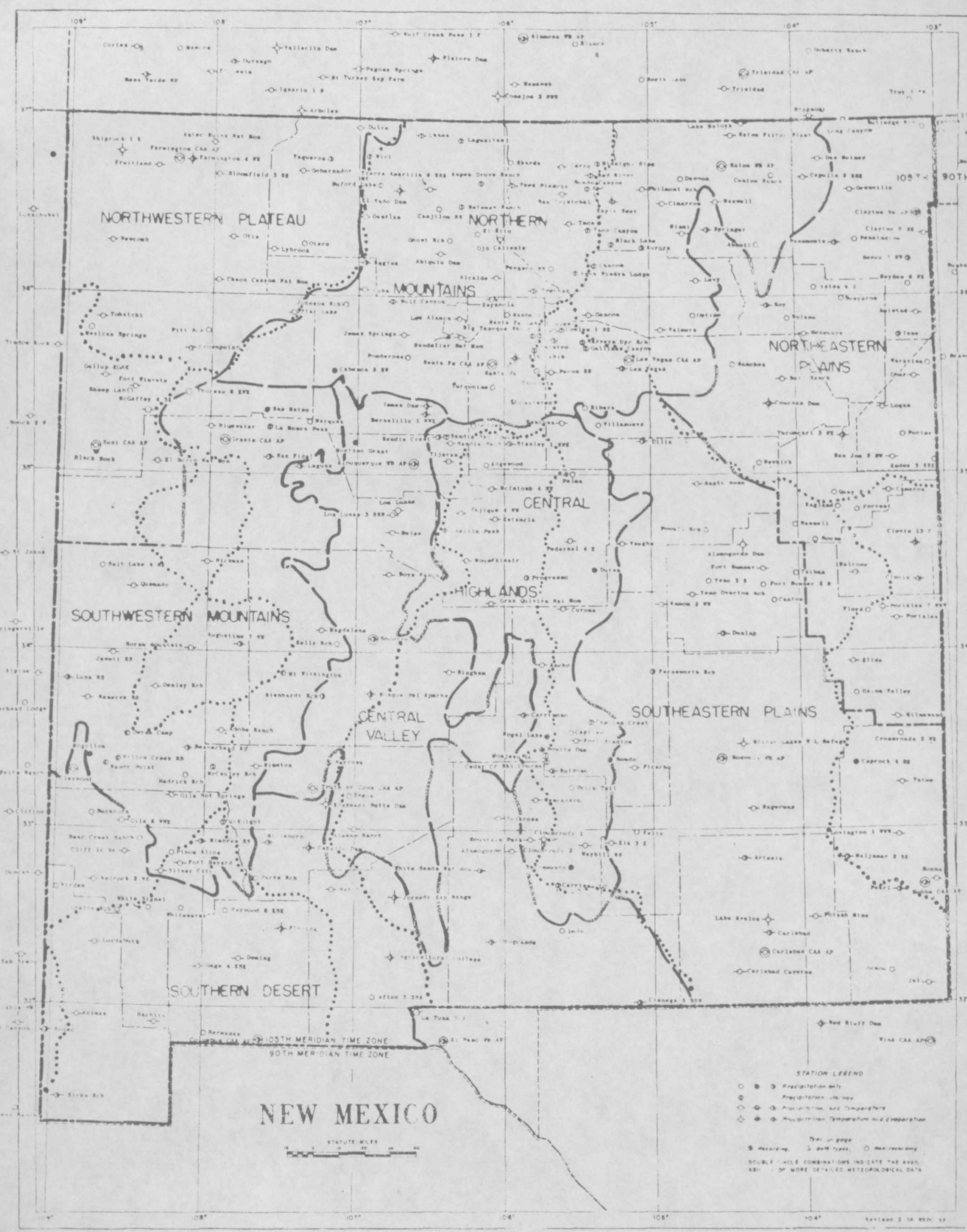

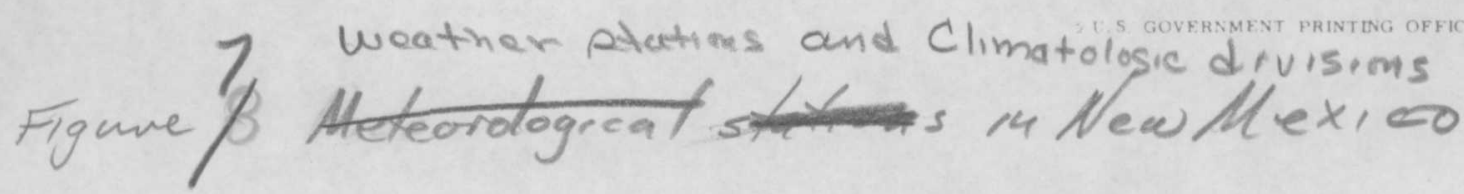




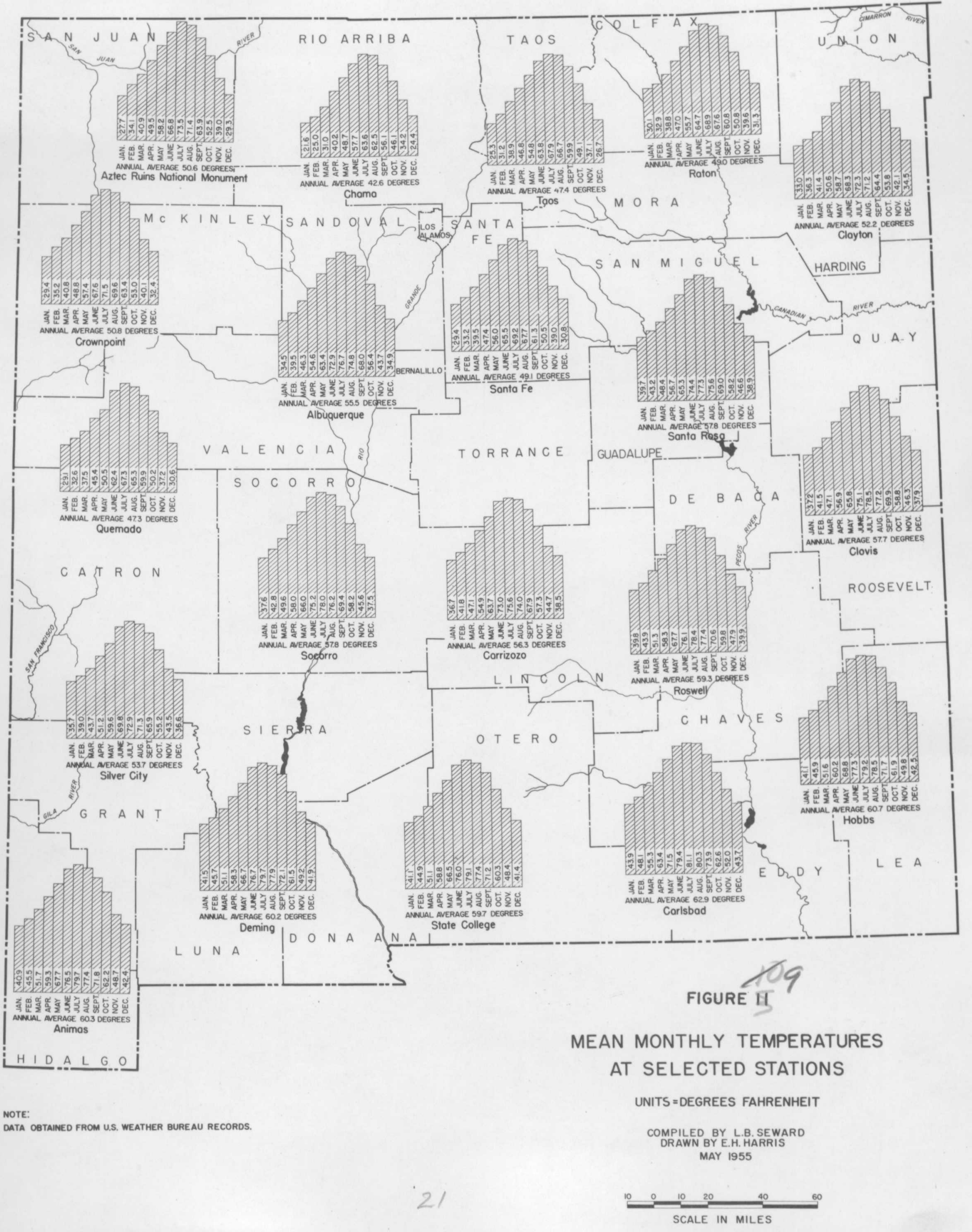




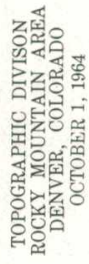

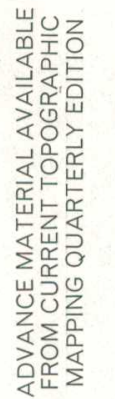

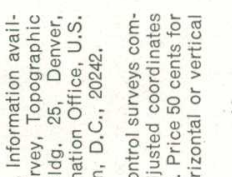

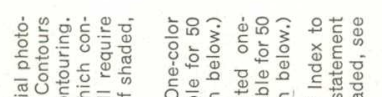

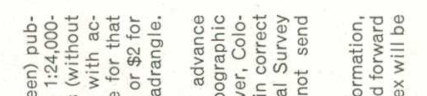

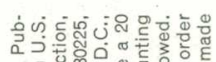

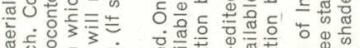

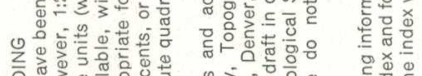

音

ه

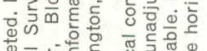

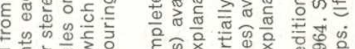

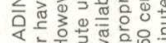

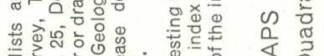

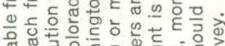

类

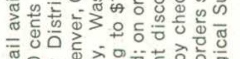

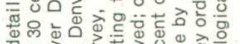

0
D.

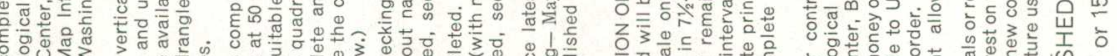

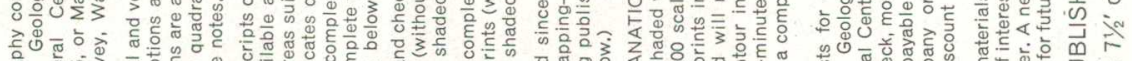

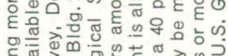

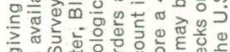

× वे

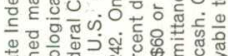

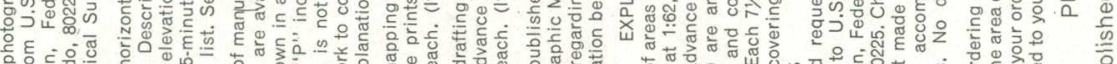

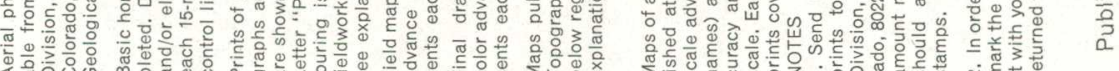

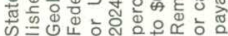

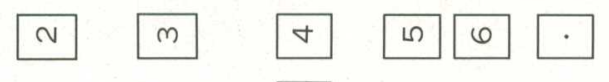

0

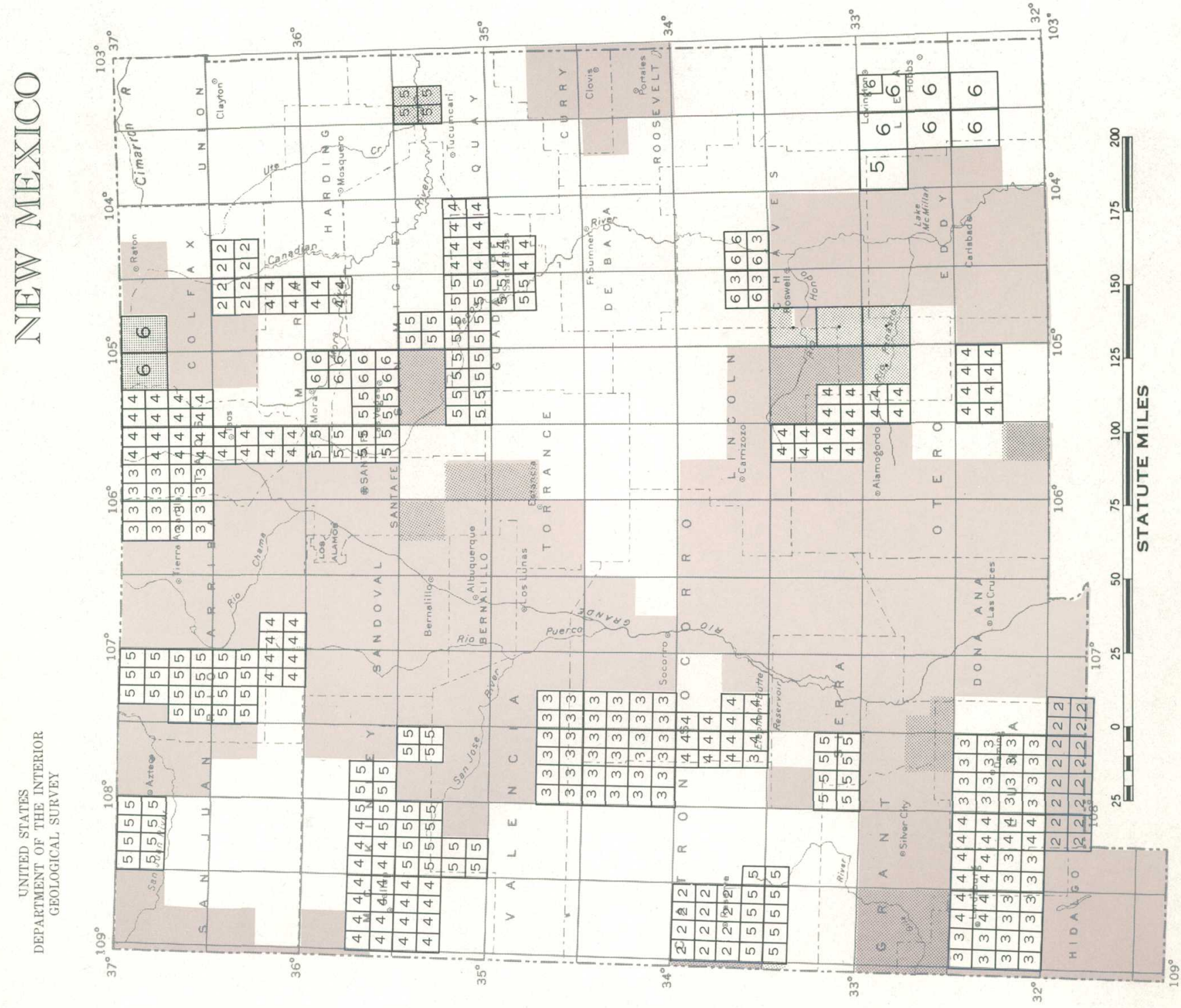




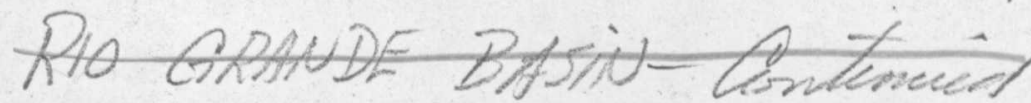
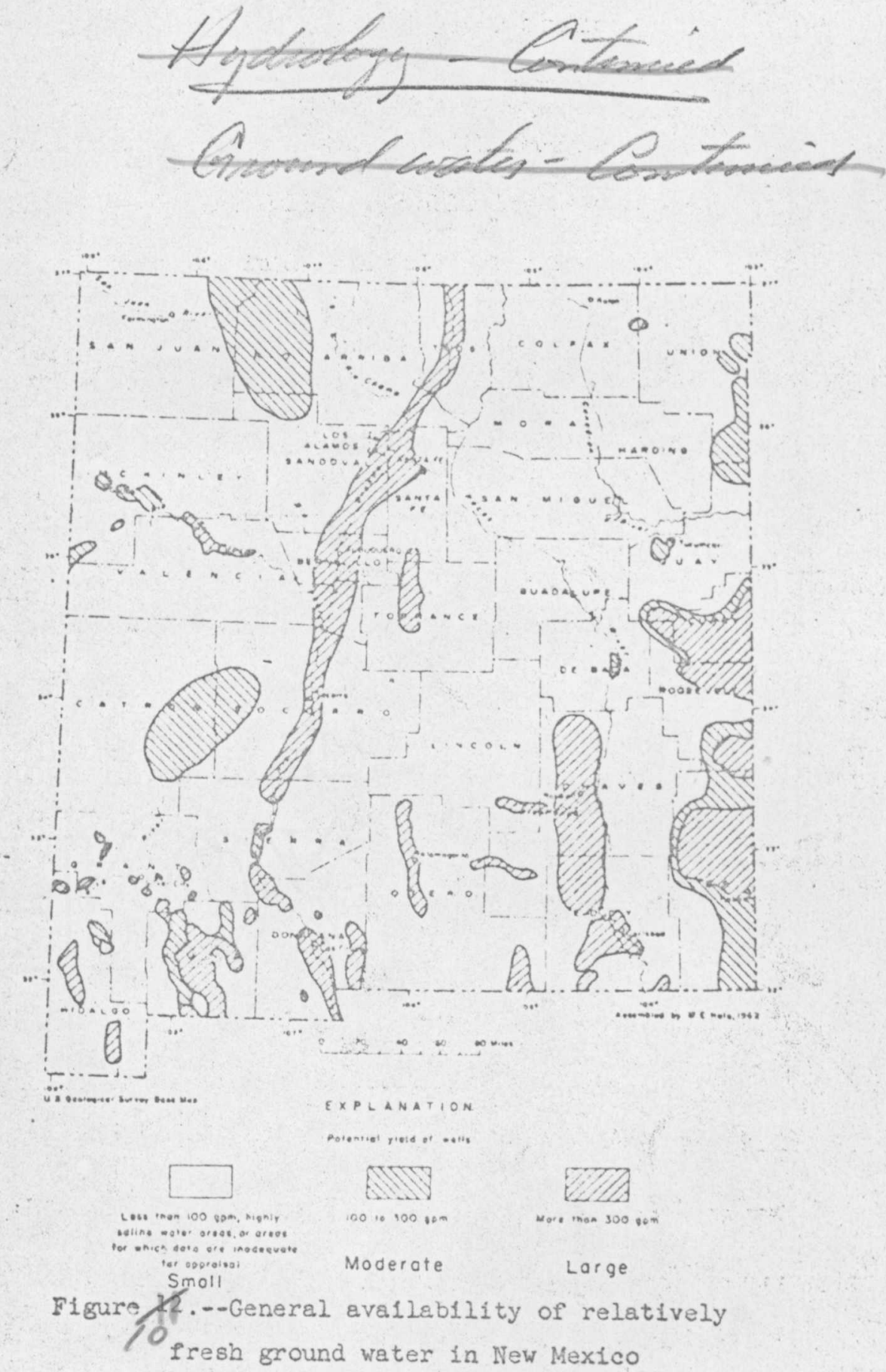

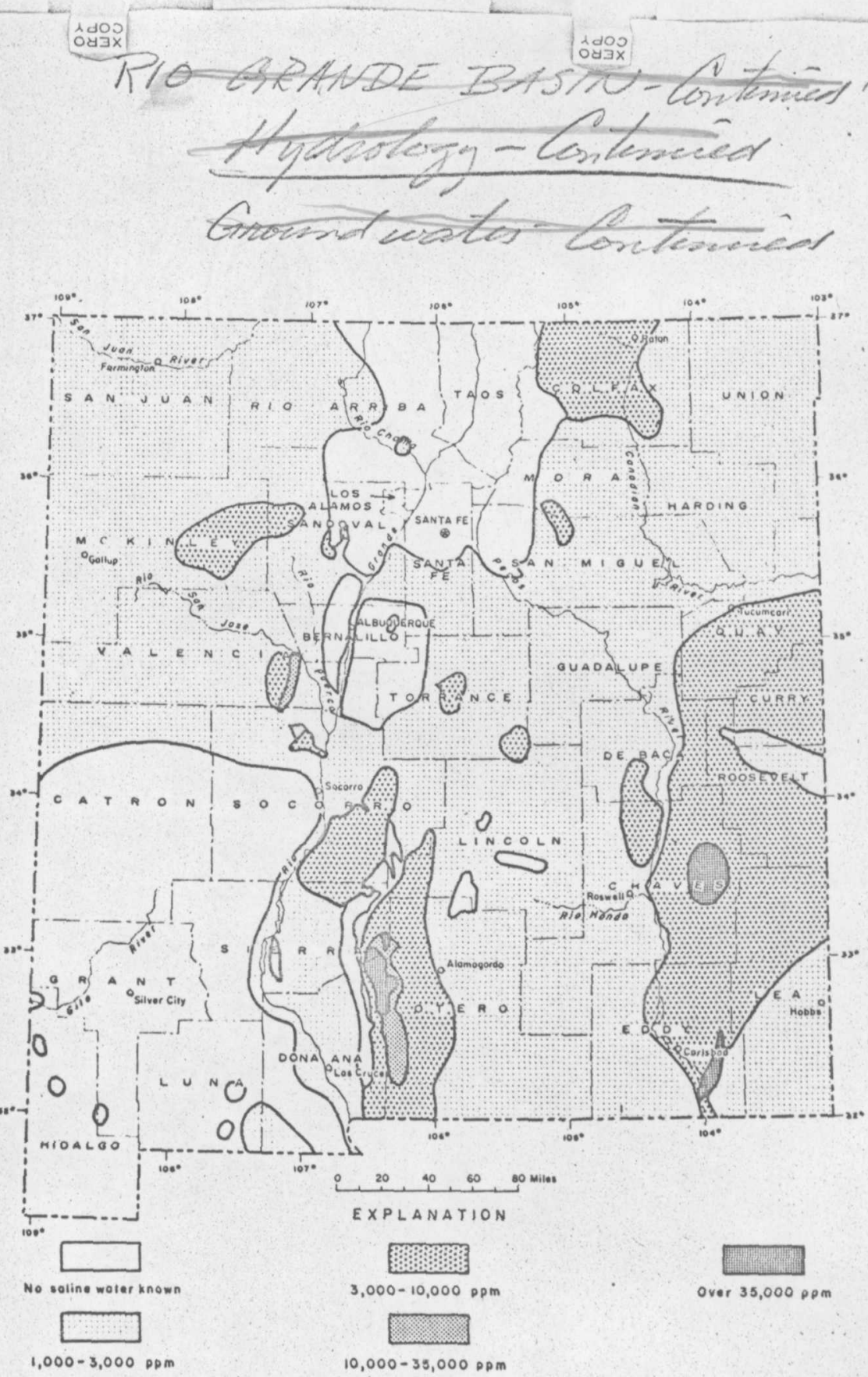

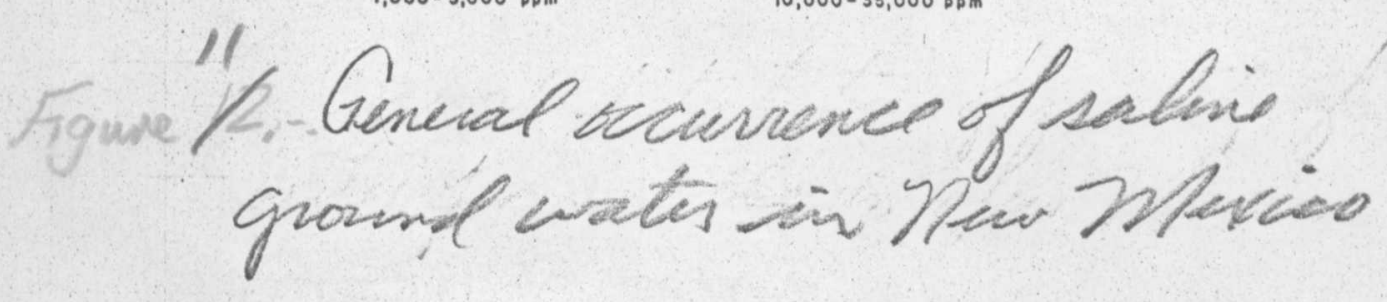

ister copy. 


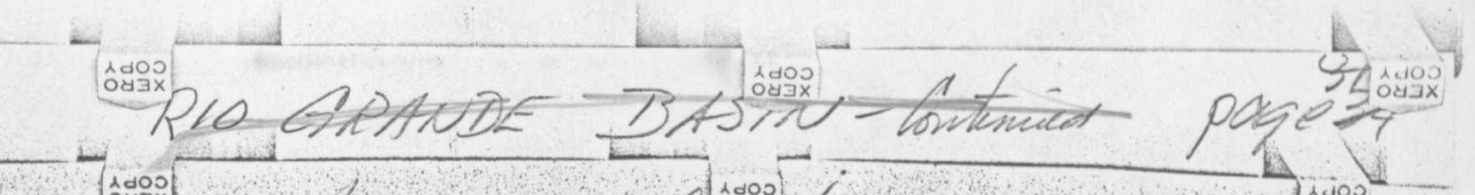
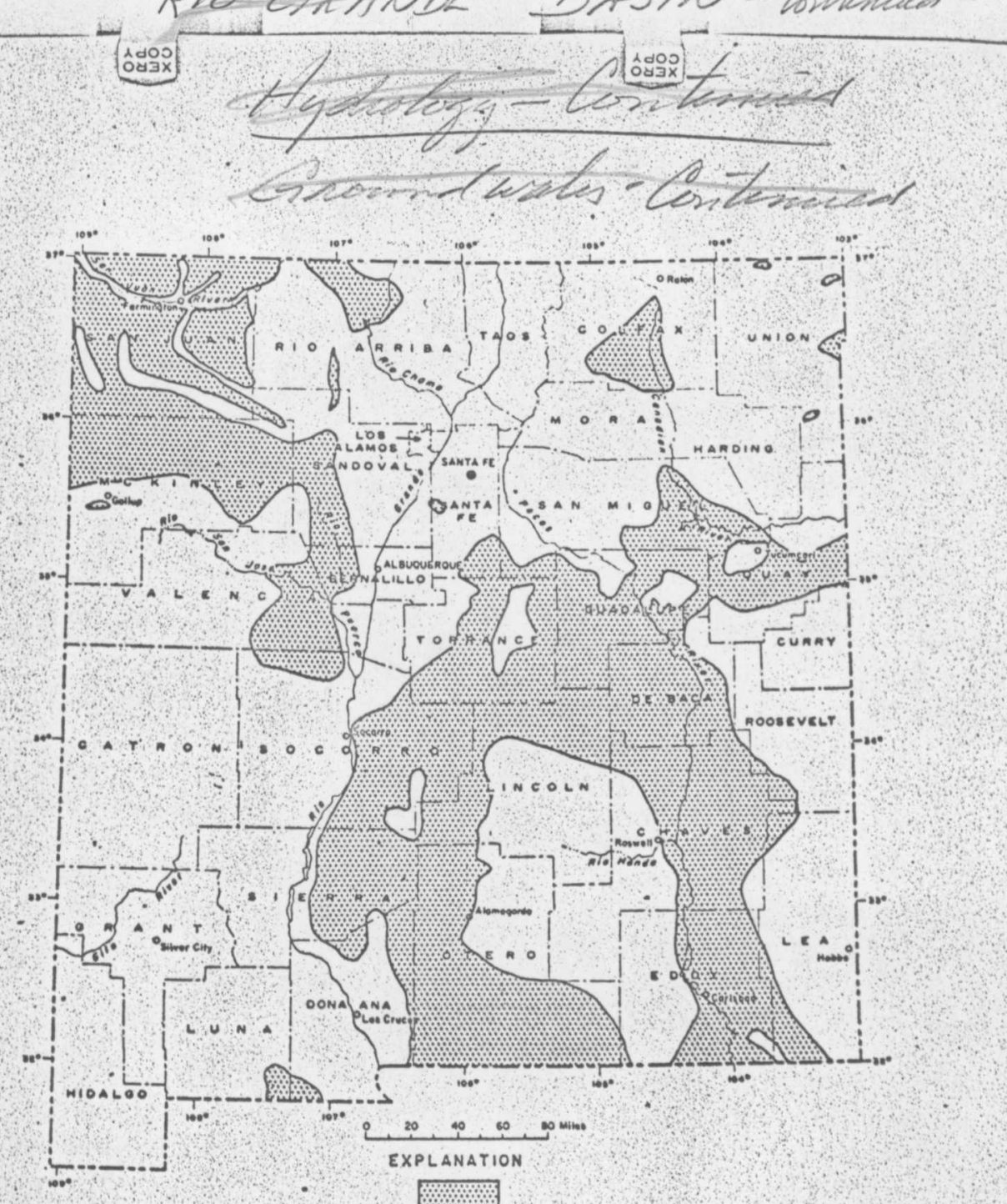

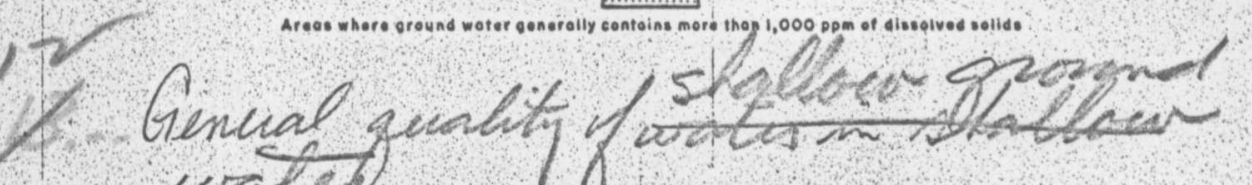
wotele in Nlew Mivico 

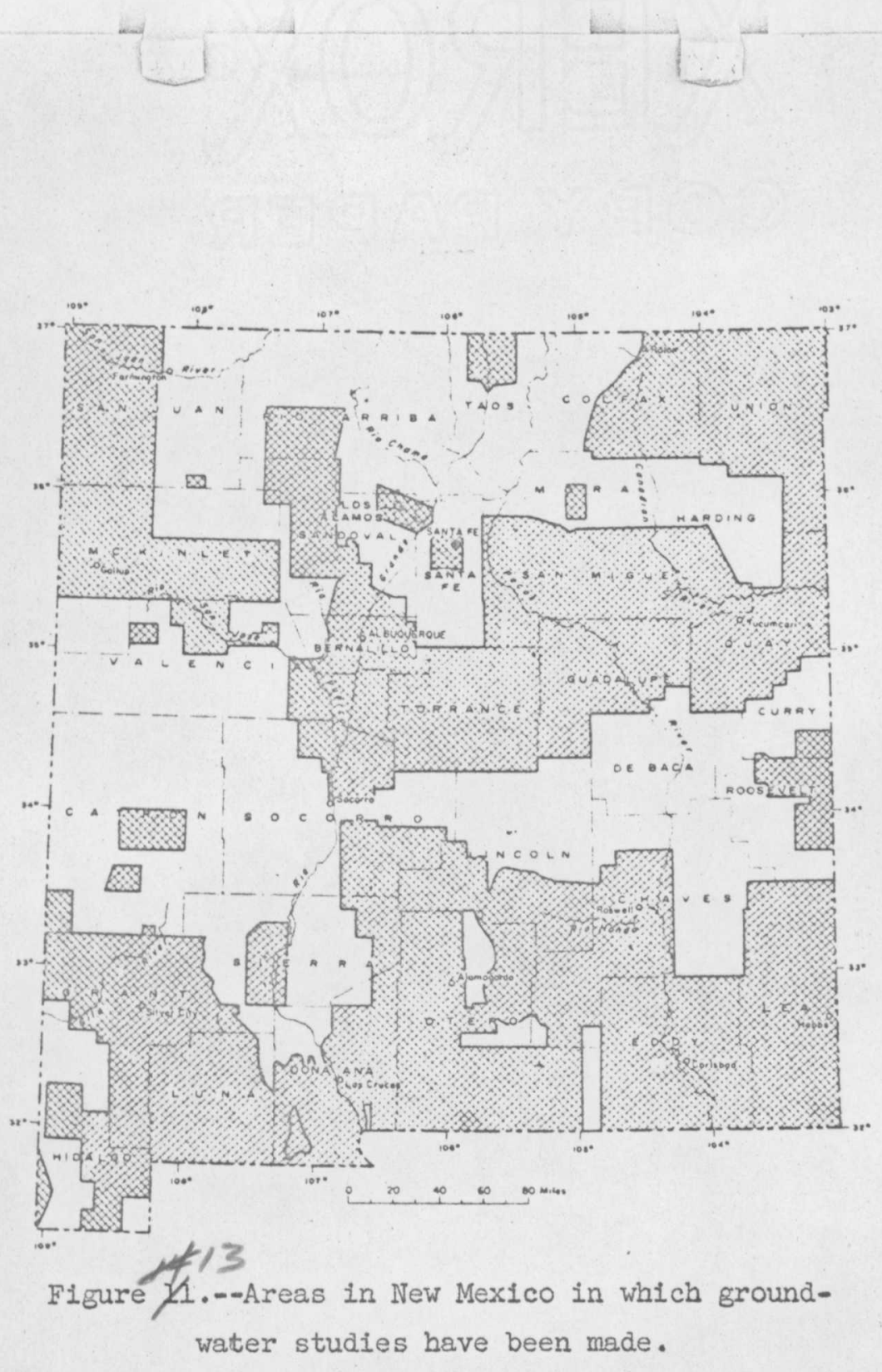


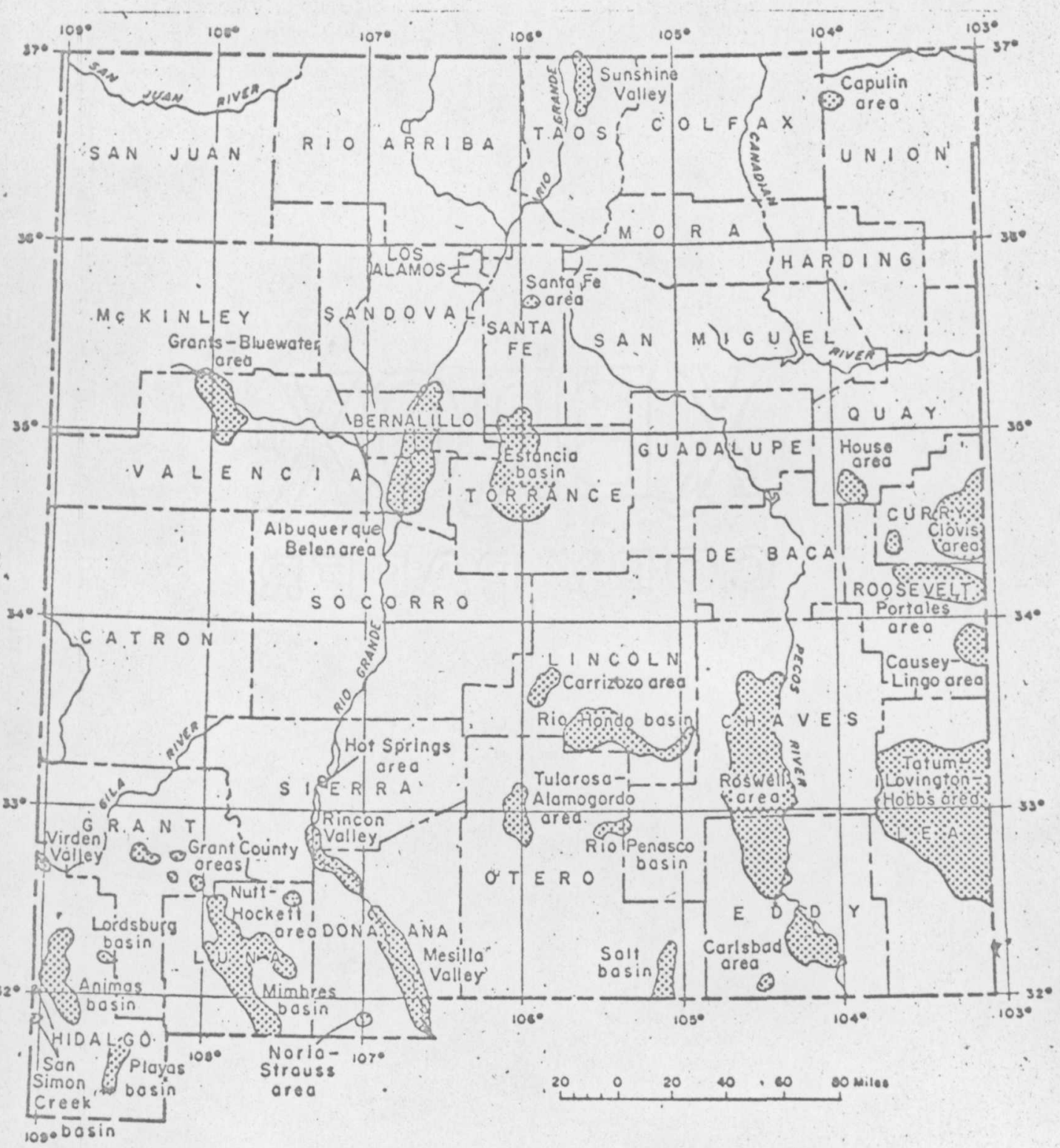

Figure $12.1 \%$ Pluctuation in New Mexico 

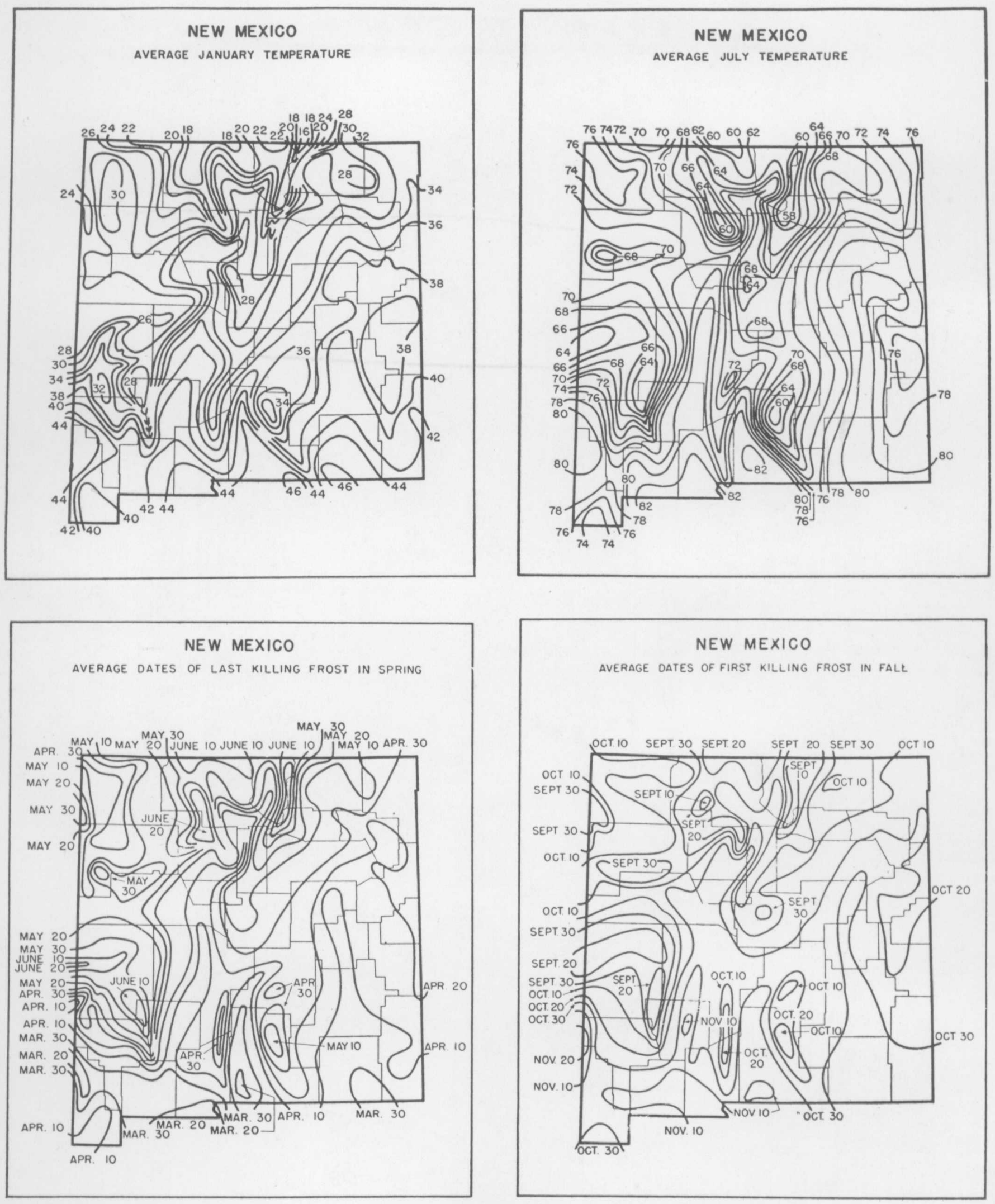

FIGURE $/ 28$

GRAPHS SHOWING AVERAGE JANUARY AND JULY TEMPERATURES AND AVERAGE DATES OF LAST KILLING FROST IN SPRING AND FIRST KILLING FROST IN FALL (From Climate and Man-Yearbook of Agriculture, 1941) 


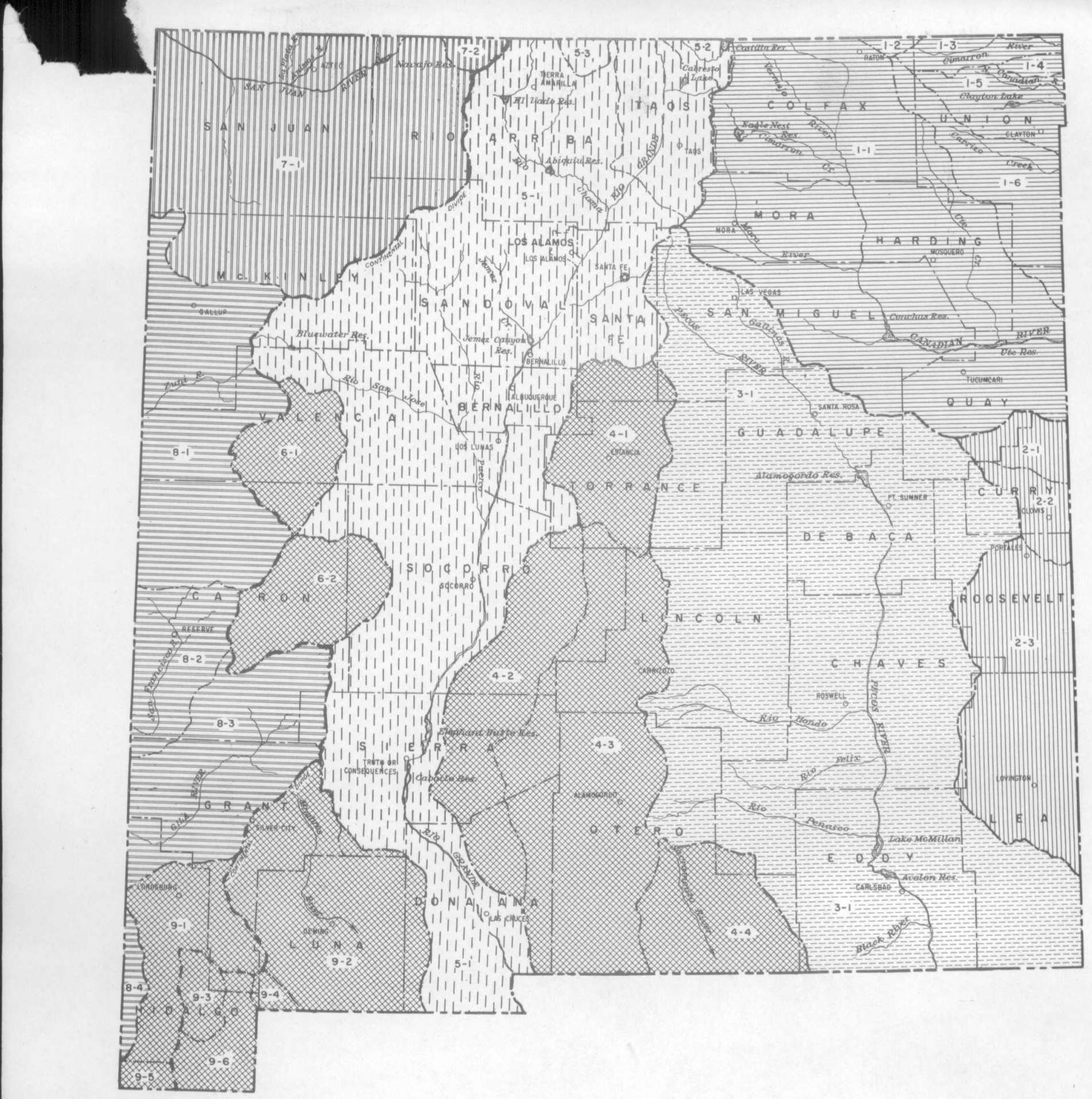

BASIN INDEX

ARKANSAS RIVER BASIN

$1-1$, CANADIAN RIVER

$1-2$, PURGATOIRE RIVER

1 - 3, CIMARRON RIVER

1 - 4, CARRIZOZO CREEK

1 - 5, NORTH CANADIAN RIVER

1- 6, CARRIZO CREEK

SOUTHERN HIGH PLAINS

2-I, RED RIVER

2-2, BRAZOS RIVER

2-3, LEA PLATEAU

PECOS RIVER BASIN

3-I, PECOS RIVER

CENTRAL CLOSED BASINS

4-I, ESTANCIA BASIN

4-2, JORNADA DEL MUERTO BASIN

4-3, TULAROSA BASIN

4-4, SALT BASIN
RIO GRANDE BASIN

5-1, RIO GRANDE

5-2, COSTILLA CREEK

$5-3$, RIO SAN ANTONIO

WESTERN CLOSED BASINS

$6-1$, NORTH PLAINS

$6-2$, SAN AUGUSTIN PLAINS

SAN JUAN RIVER BASIN

$7-1$, SAN JUAN RIVER

7-2, NAVAJO RIVER

LOWER COLORADO RIVER BASIN

8 -I, LITTLE COLORADO RIVER

8 -2, SAN FRANCISCO RIVER

8-3, GILA RIVER

$8-4$, SAN SIMON CREEK

SOUTHWESTERN CLOSED BASINS

9 - I, ANIMAS BASIN

$9-2$, MIMBRES BASIN

$9-3$, PLAYAS BASIN

9-4, WAMEL BASIN

9-5, SAN LUIS BASB

9-6, MACHITA BASIN

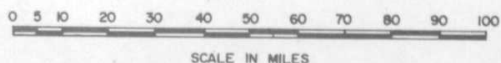

SCALE IN MILES 